Vol. 15 (2006): 106-123.

\title{
Effects of repeated phosphorus fertilisation on field crops in Finland I. Yield responses on clay and loam soils in relation to soil test $P$ values
}

\author{
Into Saarela \\ MTT Agrifood Research Finland, Plant Production Research, Soil and Plant Nutrition, \\ FI-31600 Jokioinen, Finland, e-mail: into.saarela@mtt.fi \\ Yrjö Salo and Martti Vuorinen \\ MTT Agrifood Research Finland, Plant Production Research, FI-21500 Piikkiö, Finland
}

\begin{abstract}
In order to update phosphorus $(\mathrm{P})$ fertiliser recommendations for the Finnish clay and loam soils enriched with applied $\mathrm{P}$, the effects of repeated $\mathrm{P}$ fertilisation on the yields of cereal and other crops were measured at eight sites over a period of 12-18 years. Yield results of some earlier field studies were also used in calibrating the soil test $\mathrm{P}$ values determined by the Finnish acid ammonium acetate method $\left(\mathrm{P}_{\mathrm{Ac}}\right)$. Significant yield responses to $P$ fertilisation were obtained on soils which had low $P_{A c}$ values or medium levels of $P_{A c}$ and too low or too high $\mathrm{pH}$ values ( $<6.0$ or 7.5 in water suspension). The mean relative control yield (RCY, yield without applied $\mathrm{P}$ divided by yield with sufficient $\mathrm{P}$ multiplied by 100 ) of the eight sites was $94.6 \%$ $\left(\mathrm{n}=128\right.$, mean $\mathrm{P}_{\mathrm{Ac}} 15.5 \mathrm{mg} \mathrm{dm}^{-3}$ ) varying from $87 \%$ at $\mathrm{P}_{\mathrm{Ac}} 2.8 \mathrm{mg} \mathrm{dm}^{-3}$ to $100 \%$ at high $\mathrm{P}_{\mathrm{Ac}}$. A $\mathrm{P}_{\mathrm{Ac}}$ level of 5-7 mg dm${ }^{-3}$ was adequate for cereals, grasses and oilseed rape on the basis of the RCY value of $95 \%$ at optimal pH. At this $\mathrm{P}_{\mathrm{Ac}}$ replacing the amounts of $\mathrm{P}$ in the crops $(14 \mathrm{~kg}$ in $4 \mathrm{t}$ grain) and the fixation of extractable $\mathrm{P}$ (about $6 \mathrm{~kg} \mathrm{ha}^{-1} \mathrm{a}^{-1}$ ) produced almost maximum yields in favourable seasons and were considered optimal.
\end{abstract}

Key words: Acid ammonium acetate method, optimal soil test P, soil acidity, soil phosphorus

\section{Introduction}

The supply of essential elements to crops to replace the nutrients removed from the soil is an in- dispensable requirement for efficient and sustainable food production. Inherently and anthropogenically very rich soils can produce large yields for decades without any phosphorus (P) application (Johnston and Poulton 1992, Wechsung and Pagel 
Vol. 15 (2006): 106-123.

1993). However, a major part of the arable soils of less developed countries have very low soil test $\mathrm{P}$ values (Sillanpää 1982). Rather poor soils needing regular fertilisation are not uncommon even in $\mathrm{Eu}-$ rope. The availability of $\mathrm{P}$ to crops is still insufficient at least in the sandy and silty soils in the northern and eastern parts of Finland (Saarela et al. 1995, Saarela 1998b) and in some Lithuanian soils (Vaishvila et al. 2000).

Coastal clay and loam soils of southern and western Finland have shown to be better sources of $P$ than the silty and sandy soils of the inland regions (Salonen and Tainio 1957, Saarela et al. 1995). In some other northern clay and loam soils the long-term supply of $\mathrm{P}$ has remained fairly good. At five sites in central Sweden in 1963-1996 (Carlgren and Mattsson 2001) the mean yield obtained with $\mathrm{N}$ (treatment $\mathrm{A}$ ) was $87 \%$ of that with $\mathrm{N}$ plus replacement of $\mathrm{P}$ and $\mathrm{K}$ (treatment $\mathrm{C} 2$ ). The mean latest soil test $\mathrm{P}$ value by the ammonium lactate method was $33 \mathrm{mg} \mathrm{kg}^{-1}$ (range $13-98 \mathrm{mg} \mathrm{kg}^{-1}$, classes I to IV of five classes). On five soils in southern Sweden, cereals and grasses produced even higher relative yields without applied $\mathrm{P}$ and $\mathrm{K}$, while the sugar beet yield dropped to $63 \%$.

The role of $\mathrm{P}$ in Finnish agriculture was discussed in a review (Saarela 2002) as an introduction to a project for optimising P fertilisation of crops grown on the soils enriched with P. Soil and crop data and summaries of the results were reported in Finnish (Saarela et al. 1995) and studies on the twenty-four soils of the project were published in English (Saarela et al. 2003, 2004). Eight of the field experiments were conducted on lowsilt clay and loam soils, which cover almost one million hectares or about $35 \%$ of the cultivated land. Finnish clay and loam soils are mainly used for grain production, while sugar beets, oilseed rape and ley for ensilage, hay and grazing are cultivated in smaller areas on these soils.

In order to update $\mathrm{P}$ fertiliser recommendations on the basis of chemical soil tests, the yield responses of crops to repeated $\mathrm{P}$ fertilisation in relation to soil test $\mathrm{P}$ values at eight clay and loam soils are reported in this paper. The effects of four rates of applied $\mathrm{P}$ and the control treatment were recorded for twelve to eighteen successive growth seasons at each site. The annual yield variations in relation to soil properties and weather conditions were studied at three sites, and key points of other sites are discussed. The immediate effect of applied $\mathrm{P}$ on the treated crop and the cumulative residual effect of repeated $\mathrm{P}$ fertilisation were compared at two sites.

For better reliability and applicability of the results, the soil test $\mathrm{P}$ values determined by the Finnish acid ammonium acetate method $\left(\mathrm{P}_{\mathrm{Ac}}\right.$, Vuorinen and Mäkitie 1955) were calibrated by including appropriate other studies in the summaries of results. The yield effects of repeated $\mathrm{P}$ fertilisation were mainly examined on the basis of the relative control yield, RCY, and relative yield, RY. Relative control yield is the ratio of the yield obtained without $\mathrm{P}$ fertilisation to the yield obtained with sufficient $\mathrm{P}$ fertilisation, and $\mathrm{RY}$ is the corresponding ratio of the yields obtained with insufficient and sufficient amounts of $\mathrm{P}$.

\section{Results from earlier studies}

Yield and soil test data were compiled from twenty-four sites, and the last years were presented separately for four sites (Table 1). In the experiments conducted prior to the late 1960s, cereals and clover-grass ley were grown in rotation with some other crops, fertilisers were spread on the soil and incorporated by harrowing in tilled soils and plant residues were removed. Later, cereals were grown alone or with a few oilseed rape crops in rotation, fertilisers were applied by the placement method and plant residues were returned to the soil; grass was grown in two short-term studies.

The RCY values obtained with repeated P fertilisation showed that most clay and loam soils supplied sufficient $\mathrm{P}$ to produce relatively good yields. The yield response to $\mathrm{P}$ fertilisation was small even at the medium level of $\mathrm{P}_{\mathrm{Ac}}$, if the $\mathrm{pH}_{\mathrm{w}}$ value was not lower than 6.0 or unusually high (Table 1). The yield effect of periodical animal manure application on a clay soil in Tammela was 
Saarela, I. et al. Effects of repeated P fertilisation on field crops: clay and loam soils

Table 1. Effects of annual P fertilisation, periodical manure application (ref. 1) and initial liming with ground limestone (L) on crop yields and soil test $\mathrm{P}$ values $\left(\mathrm{P}_{\mathrm{Ac}}\right)$ in clay and loam soils in Finland.

\begin{tabular}{|c|c|c|c|c|c|c|c|c|c|c|}
\hline \multirow{2}{*}{$\begin{array}{l}\text { Location } \\
\text { Latitude (N) }\end{array}$} & \multirow[t]{2}{*}{ Soil type } & \multirow{2}{*}{$\begin{array}{l}\text { Years } \\
\text { (Soil test) }\end{array}$} & \multirow{2}{*}{$\begin{array}{l}\text { Soil amen- } \\
\text { dings }\end{array}$} & \multicolumn{2}{|c|}{ P kg ha ${ }^{-1} \mathrm{a}^{-1}$} & \multirow{2}{*}{$\begin{array}{l}\text { Yield }^{1)} \\
\text { NPK }\end{array}$} & \multirow{2}{*}{$\begin{array}{c}\mathrm{RCY}^{2)} \\
\mathrm{NK}\end{array}$} & \multirow{2}{*}{$\begin{array}{c}\text { Soil } \mathrm{P}_{\mathrm{Ac}}{ }^{3)} \\
\mathrm{NK}\end{array}$} & \multirow{2}{*}{$\begin{array}{l}\text { Soil } \\
\mathrm{pH}_{\mathrm{w}}^{5)}\end{array}$} & \multirow[t]{2}{*}{$\operatorname{Ref}^{4)}$} \\
\hline & & & & $\mathrm{NK}$ & NPK & & & & & \\
\hline Tammela & Clay & $1929-53$ & Nothing & 0 & 18 & 2600 & 91 & $3.4^{6)}$ & 6.1 & 1 \\
\hline $60^{\circ} 45^{\prime}$ & & (1953) & Manure & 8 & 26 & 2710 & 98 & $4.6^{6)}$ & 6.1 & \\
\hline \multirow{5}{*}{$\begin{array}{l}\text { Nakkila } \\
61^{\circ} 15^{\prime}\end{array}$} & Muddy clay, & $1947-54$ & Nothing & 0 & 24 & 2550 & 101 & 3.7 & 5.9 & 2 \\
\hline & $20 \%$ OM & (1955) & & & & & & & & \\
\hline & Muddy clay & $1947-52$ & Nothing & 0 & 18 & 2250 & 92 & 4.8 & 4.9 & 3 \\
\hline & Muddy clay, & $1947-52$ & Limed & 0 & 18 & 1920 & 100 & 4.8 & 5.0 & 3 \\
\hline & rich in $\mathrm{OM}$ & $1947-52$ & Manure & 5 & 23 & 2260 & 99 & 4.9 & 4.9 & 3 \\
\hline Pori & Muddy clay, & $1953-57$ & Limed & 0 & 18 & 2350 & 85 & 5.2 & 5.0 & 3 \\
\hline $61^{\circ} 25^{\prime}$ & lower in OM & (1953) & & & & & & & & \\
\hline Mietoinen & Muddy clay & $1964-73$ & Nothing & 0 & 18 & 3380 & 94 & 5.0 & 5.5 & 4 \\
\hline \multirow[t]{2}{*}{$60^{\circ} 40^{\prime}$} & & (1973) & Limed & 0 & 18 & 3580 & 99 & 6.1 & 6.1 & \\
\hline & & & Limed & 0 & 18 & 3700 & 101 & 8.2 & 6.9 & \\
\hline $\begin{array}{l}\text { Tikkurila } \\
60^{\circ} 15^{\prime}\end{array}$ & Clay loam & $\begin{array}{l}1969-80 \\
(1980)\end{array}$ & Limed & 0 & 25 & 4140 & 97 & 12.8 & 6.4 & 5 \\
\hline \multirow[t]{3}{*}{ Mietoinen } & Clay & 1974-92 & Nothing & 0 & 44 & 4050 & 94 & 3.6 & 6.9 & 6 \\
\hline & & 1989-92 & & 0 & $44^{7)}$ & 3340 & $87^{7)}$ & 3.6 & & \\
\hline & & (1987) & & $25^{7)}$ & $44^{7)}$ & 3340 & $92^{7)}$ & 4.8 & & \\
\hline \multirow[t]{2}{*}{ Mietoinen } & Clay & 1974-92 & Nothing & 0 & 44 & 4590 & 99 & 9.2 & 6.7 & 6 \\
\hline & & $\begin{array}{l}1989-92 \\
(1987)\end{array}$ & & 0 & $44^{7)}$ & 4690 & $100^{7)}$ & 9.2 & & \\
\hline Vihti & Clay loam & $1974-85$ & Nothing & 0 & 30 & 4440 & 84 & 2.1 & 5.4 & 7 \\
\hline $60^{\circ} 20^{\prime}$ & & $\begin{array}{l}1981-85 \\
(1985)\end{array}$ & & 0 & 31 & 4440 & 74 & 3.0 & & \\
\hline \multirow[t]{2}{*}{ Vihti } & Clay loam & $1975-85$ & Nothing & 0 & 30 & 4790 & 92 & 1.7 & 6.0 & 7 \\
\hline & & $\begin{array}{l}1981-85 \\
(1985)\end{array}$ & & 0 & 31 & 4600 & 87 & 2.9 & & \\
\hline $\begin{array}{l}\text { Hausjärvi } \\
60^{\circ} 45^{\prime}\end{array}$ & Loam & $\begin{array}{l}1978-95 \\
(1995)\end{array}$ & Nothing & 0 & 35 & 2560 & 86 & 20.0 & $7.5^{5)}$ & 8 \\
\hline $\begin{array}{l}\text { Jokioinen } \\
60^{\circ} 50^{\prime}\end{array}$ & $\begin{array}{l}\text { Clay (site } 8 \\
\text { in this study }\end{array}$ & $1982-84$ & Nothing & 0 & 60 & 4760 & 97 & 14.9 & 6.4 & 9 \\
\hline Mietoinen & Clay & $\begin{array}{l}\text { 1983-86 } \\
\text { (grass) }\end{array}$ & Nothing & 0 & 50 & 5770 & 90 & 4.3 & 5.9 & 6 \\
\hline Jokioinen & Clay & $\begin{array}{l}\text { 1991-93 } \\
\text { (grass) }\end{array}$ & Nothing & 0 & 36 & 6420 & 95 & 3.5 & 5.8 & 10 \\
\hline Jokioinen & Clay & 1991-96 & $\begin{array}{l}\text { Limed with } \\
8 \mathrm{t} \mathrm{ha}^{-1} 1993\end{array}$ & 0 & 91 & 5560 & 72 & 0.9 & 6.1 & 11 \\
\hline Mietoinen & Clay & 1991-98 & $\begin{array}{l}\text { Mean of } \\
\text { limings }\end{array}$ & 0 & 16 & 4560 & 94 & 5.2 & 6.6 & 12 \\
\hline \multirow[t]{2}{*}{ Jokioinen } & Clay & 1994-98 & As above & 0 & 49 & 4300 & 93 & 3.6 & 6.3 & 12 \\
\hline & & & $\begin{array}{l}\text { Deep ploug- } \\
\text { ing }(32 \mathrm{~cm})\end{array}$ & 0 & 49 & 4370 & 93 & 3.1 & 6.3 & \\
\hline \multirow[t]{2}{*}{ Jokioinen } & Clay (site 8 & 1994-98 & Nothing & 0 & 23 & 4540 & 96 & 30.5 & 6.5 & 12 \\
\hline & in this study & & Limed & 0 & 23 & 4610 & 96 & 43.0 & 6.9 & \\
\hline
\end{tabular}

1) Yield unit: $1.0 \mathrm{~kg}$ cereal grain, $0.5 \mathrm{~kg}$ rapeseed or 1.0 feed unit grass equivalent to $1.0 \mathrm{~kg}$ barley grain

2) Relative control yield. Yield with NK devided by the yield with NPK expressed in per cent

${ }^{3)} \mathrm{mg} \mathrm{Pdm}^{-3}$ soil

4) References: 1 = Salonen and Tainio 1956, 2 = Salonen and Tainio 1957, 3 = Salonen 1963, 4 = Jaakkola et al. 1977,

$5=$ Experiments conducted by Göthe Larpes, $6=$ Unpublished experiments conducted by Jaakko Köylijärvi

7 = Yli-Halla 1989, 8 = Jaakkola et al. 1997, 9 = Saarela 1989 and 1991, 10 = Hakkola 1998, 11 = Saarela

1998a, 12 = Saarela et al. 2000 and unpublished results from site 8 of this study

5) Soil $\mathrm{pH}$ measured in water suspension. The $\mathrm{pH}_{\mathrm{w}}$ value of Hausjärvi was derived from the $\mathrm{pH}$ value 7.0 measured in $0.01 \mathrm{M} \mathrm{CaCl}_{2}$.

6) The $\mathrm{P}_{\mathrm{Ac}}$ values of Tammela were approximated from those extracted in $0.01 \mathrm{M} \mathrm{HCl}$ (Keränen et al. 1963).

7) Residual effects of previous $\mathrm{P}$ fertilisation 
Vol. 15 (2006): 106-123.

remarkably good (ref. 1 in Table 1). The supply of $\mathrm{P}$ and possible indirect effects of animal manure were sufficient for maximum yields in clover-grass ley and other cereals, but not for winter rye and rutabaga. One manuring supplied sufficient $\mathrm{P}$ in a shorted study on a muddy clay soil in Nakkila (ref. 3 ). The amounts of $P$ applied in manure were roughly similar to those nowadays transferred from the soil to the straw, which were removed up till the early 1970s and later in Hausjärvi (ref. 8), but returned to the soil in other recent studies.

The young muddy Litorina soils found at Nakkila and Mietoinen (ref. 4 in Table 1) probably supplied significant amounts of $\mathrm{P}$ from below the plough layer. The two heavy glacial clays in Mietoinen (ref. 6) were located close to the sites 1 and 3 of this study (Saarela et al. 2003). Soil acidity was clearly detrimental for $\mathrm{P}$ availability in the unlimed muddy clay in Mietoinen. Exceptionally high $\mathrm{pH}$ was an obvious reason for the exceptional results in Hausjärvi, in accordance with the relatively poor availability of $\mathrm{P}$ at high $\mathrm{pH}$ and $\mathrm{P}_{\mathrm{Ac}}$ (Aura 1978). The decline of the quadratic $\mathrm{pH}$-correction equation at very high $\mathrm{pH}$ values (Saarela 1992) also implied that the availability of $P$ in relation to $\mathrm{P}_{\mathrm{Ac}}$ is poor at excessive $\mathrm{pH}$. The removal of plant residues in contrast to other recent experiments is another possible reason for the untypical yield responses in Hausjärvi.

The control plots not fertilised with superphosphate received little or no fertiliser sulphur. However, the field studies conducted in Southern Finland (Korkman 1973) suggest that the low grade potassium fertilisers used in the oldest experiments and the acid rain since the 1960s probably supplied sufficient sulphur to the crops.

\section{Material and methods}

\section{Experimental soils}

The eight clay and loam soils of this study (Table 2, Fig. 1) include three types of mineral soils: i) glacial clay and clay loam containing $30 \%$ or more clay (soils 1, 3, 7 and 8), ii) glacial loam with 12-30\% clay (soils 2 and 5) and iii) the younger Litorina sediments or muddy clay (soils 4 and 6). The glacial soils which contain $12-30 \%$ clay, but relatively little fine silt, belong to the Finnish soil types fine sand and very fine sand, sometimes specified as clayey. The experiments on silt loam and silty clay loam soils will be published later together with the results from sandy soils.

A summary of the P status and other characteristics of the clay and loam and soils studied earlier (Saarela et al. 2003, 2004) is presented in Table 2. Some additional soil test $\mathrm{P}$ values determined in an international comparison of chemical methods (Saarela et al. 1996) are also presented. The ammonium lactate $\mathrm{P}$ values (Egnér et al. 1960) are medium (41-80) or high according to Swedish calibration, while some of the calcium lactate $\mathrm{P}$ values are rather low according Estonian calibration (medium $=31-61$ ). The values for resin $\mathrm{P}$ (van Raij 1998) are all high according to Brazilian ratings for agriculture (high $=41-80$ ). The $\mathrm{CaCl}_{2}$

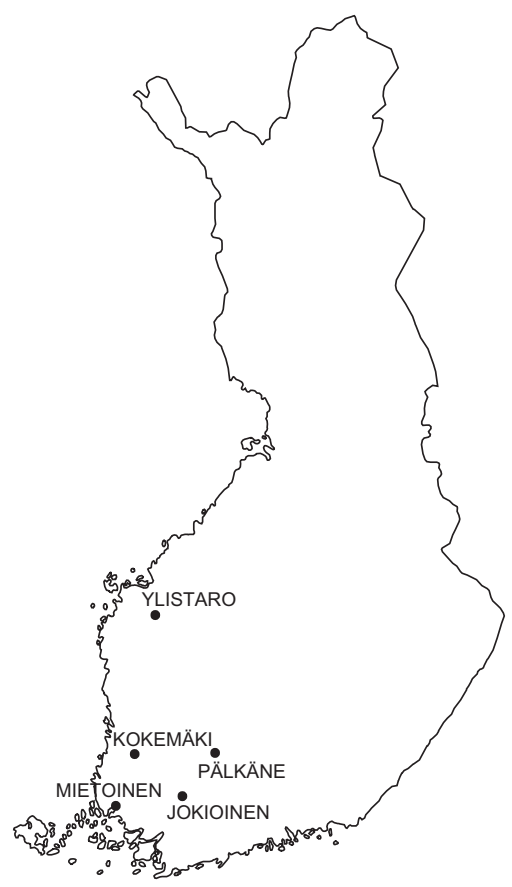

Fig. 1. Location of the experimental sites. 
Saarela, I. et al. Effects of repeated P fertilisation on field crops: clay and loam soils

Table 2. Soil characteristics and $\mathrm{P}$ status of the plough layer at each experimental site in clay and loam soils with "low" (CLP1) "high" (CLP2) and mean (CLPM) concentration of P extractable in acid ammonium acetate $\left(\mathrm{P}_{\mathrm{Ac}}\right)$.

\begin{tabular}{|c|c|c|c|c|c|c|c|c|c|c|c|c|c|c|c|}
\hline $\mathrm{o} /$ & & $\begin{array}{l}\mathrm{OC} \\
\%^{1)}\end{array}$ & $\begin{array}{c}\text { Clay, } \\
\%\end{array}$ & $\mathrm{pH}_{2)}$ & $\begin{array}{l}\text { CATS }^{3)} \\
\mathrm{cmol}^{(+)} \\
\mathrm{dm}^{-3}\end{array}$ & $\begin{array}{l}\text { Total } \\
\mathrm{P} \\
\mathrm{g} \mathrm{kg}^{-1}\end{array}$ & $\begin{array}{l}\text { P satu- } \\
\text { ration, } \\
\%^{4)}\end{array}$ & $\begin{array}{l}\text { Sorp- } \\
\text { tion } \\
\text { index }\end{array}$ & Ac & J & $n$ & $\frac{\mathrm{s}, \mathrm{P}_{\mathrm{x}}}{\mathrm{Al}}$ & $\mathrm{Cal}$ & $\frac{\mathrm{re} x=}{\mathrm{CaCl}_{2}}$ & \\
\hline 1 & & & & 6.5 & & & 6.2 & & 3.9 & 4. & 3 & 0 & 22 & 0.2 & \\
\hline & & & & & & & & & & 5. & & 29 & 13 & 0.3 & 49 \\
\hline 3 & & & & & & & & & & & & 59 & 35 & 5) & \\
\hline 4 & & & & & & & & & 5 . & 1. & 6 & 80 & 50 & 0.4 & 77 \\
\hline & & & & & & & & & & & 39 & 59 & 30 & 0.4 & 78 \\
\hline 5 & & & & & & & & & 8. & 5. & 41 & 64 & 35 & 0.7 & 75 \\
\hline 6 & & & & & & & & & & & & 36 & 2 & 7 & 123 \\
\hline & & & & & & & & & 14 & & & 107 & 65 & 0.6 & 156 \\
\hline- & & 2. & & & & & & & & & & 240 & 131 & 5.2 & 446 \\
\hline & & 3 & & 6.0 & & & 10.1 & & 22.2 & 19.1 & 74 & 137 & 76 & 1.8 & 200 \\
\hline-8 & CLPM & 3.5 & 37 & 5.9 & 11.8 & 1.22 & 8.0 & 0.76 & 13.6 & 11.7 & 56 & 98 & 53 & 1.1 & 139 \\
\hline
\end{tabular}

1) Organic carbon

2) At site 4 soil $\mathrm{pH}$ increased to 5.7 after liming with $5 \mathrm{t} \mathrm{ha}^{-1}$ in 1985

In the limed plots at site 8 soil $\mathrm{pH}$ increased to 7.0

3) $\mathrm{CATS}=$ sum of extractable $\mathrm{Ca}, \mathrm{K}$ and $\mathrm{Mg}$ measured by the acid ammonium acetate method (Saarela et al. 2003)

4) Amm. fluoride and sodium hydroxide extractable P divided by acid oxalate extractable Al and Fe (Saarela et al. 2003)

5) Sorption of $0.2 \mathrm{~g} \mathrm{P} \mathrm{kg}^{-1}$ soil in $0.005 \mathrm{M} \mathrm{CaCl}_{2}$ in one week divided by the final solution $\mathrm{P}$ concentration, $\left(\mathrm{g} \mathrm{kg}^{-1}\right)\left(\mathrm{mg} \mathrm{dm}^{-3}\right)^{-1}$ (Saarela 1992)

6) $\mathrm{P}_{\mathrm{w} 60}=$ water extraction, ratio1:60 by volume, $\mathrm{P}_{\mathrm{Olsenm}}=$ modified Olsen $\mathrm{P}$ mg kg-1, $\mathrm{P}_{\mathrm{Al}}=$ ammonium lactate extraction by SLU, Sweden, $\mathrm{mg} \mathrm{P} \mathrm{kg}^{-1}$ (S. Engblom), $\mathrm{P}_{\text {Cal }}=$ calcium lactate extraction by ERIA, Estonia, $\mathrm{mg} \mathrm{P} \mathrm{kg}^{-1}$

(L. Kevvai), $\mathrm{P}_{\mathrm{CaCl} 2}=0.01 \mathrm{M} \mathrm{CaCl}_{2}$ extraction by WAU, Netherlands, $\mathrm{mg} \mathrm{P} \mathrm{kg}^{-1}$ ( $\mathrm{S}$. van der Zee), $\mathrm{P}_{\text {res }}=$ resin extraction by IA, Brazil, mg P dm ${ }^{-3}$ (B. van Raij)

method introduced by Houba et al. (1990) extracted little $\mathrm{P}$ from most Finnish mineral soils indicating a low content of dissolved phosphate in soil solution, or a low intensity of soil $\mathrm{P}$, in agreement with $\mathrm{P}_{\mathrm{w}}$. The modified (20\% higher) Olsen $\mathrm{P}$ values are high in accordance with their quantitative character (Saarela et al. 2003).

\section{Treatments and cropping}

The treatments consisted of five annual phosphorus applications including the control and four rates of P: $0,15,30,45$ and $60 \mathrm{~kg} \mathrm{P} \mathrm{ha}^{-1}$ in $4-5 \mathrm{~m}$ by $12-20 \mathrm{~m}$ plots. Initial liming with $10 \mathrm{t} \mathrm{ha}^{-1}$ in ground limestone applied in 1980 was included in experiment 8 as another factor in the whole plots which included the five P fertilisation treatments. The whole study area of this site was treated with the same liming agent at $4 \mathrm{tha}^{-1}$ in the autumn of 1993. The main experimental plants were spring barley, spring wheat and oats, while oilseed rape, winter wheat, winter rye, perennial ley and peas were also grown in irregular rotations (Table 3). Cereals and oilseed rape were harvested with a plot combine and grasses with a plot harvester equipped with a weighing system. The crops were weighed immediately or after drying, the moisture percentage at weighing was determined gravimetrically and the dried samples were analysed for total $\mathrm{P}$ and other macronutrients.

The $\mathrm{P}$ rates were applied as single (1977-1987) or triple superphosphate (8.7 or $20 \%$ P). To cereals, rapeseeds and peas the $\mathrm{P}$ fertiliser was placed 
Vol. 15 (2006): 106-123.

Table 3. Crop succession and rates of nitrogen fertilisation $\left(\mathrm{N}, \mathrm{kg} \mathrm{ha}^{-1}\right)$ applied at the experimental sites $1-8$ in the crop years 1977-1994.

\begin{tabular}{|c|c|c|c|c|c|c|c|c|c|c|c|c|c|c|c|}
\hline Exp. & 77 & 78 & 79 & 80 & 81 & 82 & 83 & 84 & 85 & 86 & 87 & 88 & 89 & 90 & $91^{1)}$ \\
\hline \multirow[t]{2}{*}{1} & $\mathrm{sW}^{2)}$ & sw & bar & bar & oat & oat & bar & sw & oilr & bar & sw & sw & bar* & $s w$ & $b a r^{1)}$ \\
\hline & 100 & 100 & 100 & 100 & 100 & 100 & 100 & 100 & 100 & 100 & 100 & 110 & 110 & 110 & 110 \\
\hline \multirow[t]{2}{*}{2} & & bar & oat & bar & sw & oat & bar & SW & oat & fail & bar & sw & oat & sw & \\
\hline & & 55 & 55 & 55 & 55 & 55 & 55 & 55 & 55 & 55 & 55 & 55 & 55 & 55 & \\
\hline \multirow[t]{2}{*}{3} & pea & pea & pea & sw & oat & pea & sw & SW & sw & oilr & bar & sw & & & \\
\hline & 50 & 50 & 50 & 50 & 83 & 50 & 50 & 100 & 100 & 100 & 100 & 100 & & & \\
\hline \multirow[t]{2}{*}{4} & oat & oat & oat & oat & oat & oat & oat & oat & oat & bar & oilr & bar & grl & grl & grl \\
\hline & 55 & 55 & 55 & 55 & 55 & 55 & 55 & 55 & 55 & 55 & 55 & 55 & 150 & 150 & 150 \\
\hline \multirow[t]{2}{*}{5} & bar & oat & sw & oat & oat & bar & sw & bar & oat & sW & bar & sw & bar* & oat & $b a r^{1)}$ \\
\hline & 83 & 83 & 83 & 83 & 83 & 83 & 83 & 83 & 83 & 83 & 83 & 83 & 83 & 83 & 83 \\
\hline \multirow[t]{2}{*}{6} & & bar & bar & bar & oat & oat & bar & fail & bar & oat & bar & oat & sw & & \\
\hline & & 53 & 53 & 41 & 41 & 41 & 41 & 41 & 41 & 41 & 41 & 41 & 60 & & \\
\hline \multirow[t]{2}{*}{7} & & rye & rye & ww & rye & ww & rye & bar & rye & ww & rye & ww & rye & & \\
\hline & & 124 & 124 & 124 & 124 & 124 & 124 & 124 & 124 & 124 & 132 & 132 & 130 & & \\
\hline \multirow[t]{2}{*}{8} & & & & bar & bar & bar & ww & oat & oilr & sw & bar & sw & bar* & grcl & $\operatorname{grcl}^{1)}$ \\
\hline & & & & 100 & 100 & 100 & 160 & 100 & 110 & 110 & 90 & 90 & 60 & 100 & 230 \\
\hline
\end{tabular}

1) Exp. 1: 92 oilr, 93 sw, 94 sw, $115 \mathrm{~N}$ each year; Exp. 5: 92 sw, 93 oat, 94 oils, $92 \mathrm{~N}$ each year;

Exp. 8: 92 grl 200N, 93 ww 170N, 94 sw 120N;

Underlining indicates splitting of the plots with NK and NPK fertilisations

Italicising indicates withdrawal of the $\mathrm{P}$ application rates 30 and $60 \mathrm{~kg} \mathrm{ha}^{-1}$ from the year marked with * (15 and $45 \mathrm{~kg} \mathrm{ha}^{-1}$ continued).

2) Crop abbreviations: $\mathrm{sw}=$ spring wheat, bar = spring barley, oilr = oilseed rape (spring turnip rape), grl = grass ley, rye $=$ winter rye, $\mathrm{ww}=$ winter wheat, grcl $=$ grass clover ley. fail $=$ a crop failure caused by a treatment error (exp. 2 in

1986) or omitted harvesting of a lodged cereal crop (exp. 6 in 1984)

with hoe coulters in narrow bands or rows to a depth of $8 \mathrm{~cm}$ with a row distance of 12.5 or $15 \mathrm{~cm}$ before sowing. To ley the $\mathrm{P}$ fertiliser was broadcast at the beginning of the growing season. In order to measure the residual effects of previously applied $\mathrm{P}$, the $\mathrm{P}$ rates 30 and $60 \mathrm{~kg} \mathrm{ha}^{-1}$ were withdrawn beginning in the tenth (site 8 ) or thirteenth (sites 1 and 5) year. During one or three final years the plots were split with NK and NPK fertilisation (Table 3). Both fertilisers supplied exactly the same amounts of $\mathrm{N}$, and the minor differences in $\mathrm{K}$ and other nutrients were considered negligible. The mean amount of $\mathrm{P}$ applied in the NPK fertiliser was $20 \mathrm{~kg} \mathrm{ha}^{-1}$ (variation 16-25 kg P ha-1, exact amounts given by Saarela et al. 1995).

The use of compound fertilisers allowed us to apply several nutrients and the seeds in one operation by the combined fertiliser and seed drilling technique employed on most Finnish farms. The fertiliser was then placed with narrow hoe coulters ( $<15 \mathrm{~mm}$ wide) in the middle of every second 12.5 $\mathrm{cm}$ wide spaces of the seed rows drilled with shoe coulters. The distance of two adjacent fertiliser rows was thus $25 \mathrm{~cm}$, and the horizontal distance of fertiliser and seed rows was $6.2 \mathrm{~cm}$. A Finnish ammonium nitrate granulated with a mixture of ground dolomite, "Oulunsalpietari", was used as the single $\mathrm{N}$ fertiliser, and a high-grade $\mathrm{KCl}$ fertiliser was used as the $\mathrm{K}$ source.

When superphosphate was applied to the four treatments by the placement method, the control was usually drilled in the same way without any fertiliser distribution. The $\mathrm{K}$ fertiliser was placed across the $\mathrm{P}$ fertiliser rows to the depth of 5 (to avoid loosening of clay) to $8 \mathrm{~cm}$ as basal fertilisation at $60 \mathrm{~kg} \mathrm{~K} \mathrm{ha}^{-1}$ in each year. The $\mathrm{N}$ fertiliser 
Saarela, I. et al. Effects of repeated P fertilisation on field crops: clay and loam soils

Table 4. Monthly mean temperature $\left({ }^{\circ} \mathrm{C}\right)$ and precipitation $(\mathrm{mm})$ at Jokioinen, southwestern Finland $\left(60^{\circ} 52^{\prime} \mathrm{N}\right.$, $23^{\circ} 27^{\prime} \mathrm{E}$ ) during the growing seasons 1977-1994 with the means of the period 1961-1990 (Finnish meteorogical institute).

\begin{tabular}{|c|c|c|c|c|c|c|c|c|c|c|c|c|c|c|c|c|}
\hline & 77 & 78 & 79 & 80 & 81 & 82 & 83 & 84 & 85 & 86 & 87 & 88 & 89 & 90 & 91 & $92^{1)}$ \\
\hline \multicolumn{17}{|c|}{ Temperature, ${ }^{\circ} \mathrm{C}$} \\
\hline May & 8.7 & 9.8 & 10.5 & 7.0 & 11.2 & 8.5 & 11.0 & 12.6 & 8.6 & 10.5 & 7.6 & 11.4 & 10.4 & 9.3 & 7.2 & 11.4 \\
\hline June & 13.9 & 14.1 & 15.5 & 16.4 & 12.8 & 11.2 & 13.3 & 13.1 & 13.2 & 16.3 & 12.1 & 16.5 & 15.4 & 14.4 & 12.1 & 15.7 \\
\hline July & 14.2 & 14.5 & 14.2 & 16.2 & 16.2 & 16.4 & 16.6 & 14.8 & 15.3 & 16.2 & 14.8 & 19.0 & 16.3 & 15.2 & 16.6 & 16.0 \\
\hline August & 13.7 & 12.8 & 15.2 & 13.9 & 13.5 & 15.6 & 15.0 & 13.8 & 15.5 & 12.9 & 11.7 & 14.1 & 13.7 & 15.0 & 16.2 & 14.3 \\
\hline \multicolumn{17}{|c|}{ Precipitation, mm } \\
\hline May & 49 & 11 & 21 & 20 & 19 & 71 & 44 & 66 & 43 & 52 & 38 & 44 & 41 & 22 & 29 & 7 \\
\hline June & 43 & 73 & 27 & 131 & 115 & 25 & 84 & 113 & 41 & 11 & 81 & 25 & 30 & 20 & 69 & 25 \\
\hline July & 82 & 54 & 156 & 36 & 104 & 84 & 41 & 91 & 55 & 65 & 68 & 128 & 85 & 85 & 55 & 47 \\
\hline August & 54 & 101 & 112 & 76 & 88 & 111 & 58 & 69 & 119 & 110 & 83 & 79 & 92 & 90 & 92 & 107 \\
\hline
\end{tabular}

1) 1993 temperature $13.3,11.4,15.6,12,9^{\circ} \mathrm{C}$, precipitation $1,56,107$ and $136 \mathrm{~mm}$ for May, June, July and August 1994 temperature $7.8,12.1,19.0,15,1^{\circ} \mathrm{C}$, precipitation 34, 66, 1 and $54 \mathrm{~mm}$ for May, June, July and August 1961-90 temperature $13.3,11.4,15.6,12,9^{\circ} \mathrm{C}$, precipitation $1,56,107,136 \mathrm{~mm}$ for May, June, July and August

was applied with the combidrill during the same passing as the seeds and drilled across the $\mathrm{P}$ fertiliser rows to a depth of $8 \mathrm{~cm}$. The amounts of $\mathrm{N}$ applied each year are given in Table 3. The combidrill was equipped with narrow press wheels which compacted the seed rows while leaving the fertiliser rows totally uncompacted. To ley single $\mathrm{N}$ and $\mathrm{K}$ fertilisers were broadcast separately for each cut, except on the rich clay soil (8) K was applied only in spring. To winter cereals most of the $\mathrm{N}$ fertiliser was broadcast in spring.

Normal autumn ploughing was employed as the only method of primary cultivation. Seedbed was prepared by two or three passes with a S-pine harrow. Particularly in clay fields in spring, the soil was not loosened to deeper than the seeds were drilled. Spring sowing was normally done between the 10th and 25th of May. Weeds in cereals and insects in oilseed rape were controlled chemically. Early barley varieties were harvested with a plot combine during the first or middle weeks of $\mathrm{Au}-$ gust and other crops one to three weeks later. Winter cereals were sown at the end of August or early September and combined about fifty weeks later. Leys were cut two or three times in a growing season.
A summary of the weather conditions at Jokioinen during the experimental period is presented in Table 4. The seasons 1981 and 1987 were exceptionally cool and the early summer of 1982 was cool and dry. Precipitation in early summer is critical for growth and is usually less than optimal, particularly in the southern and south western coastal regions. Most of the seasons in the early and middle years of the study had an average or higher precipitation, but the seasons 1979, 1982, 1986, 1988-1990 were rather dry. The growing season of 1992 was warm and very dry.

\section{Testing and presenting results}

The five $\mathrm{P}$ fertilisation treatments were arranged in randomised blocks with four replicates. The effects of liming were studied at site 8 in four additional blocks which included the five fertilisation treatments as subplots (Saarela et al. 2003). Differences between the treatments were tested by analysis of variance for each year and for the whole study period and its parts. The multi-factorial experiments with the NK and NPK fertilisation in the subplots (final three years on soils 1 and 5) were 
Vol. 15 (2006): 106-123.

tested by using the treatment means as independent variables and the two experiments as replicates. Relationships between the yield effects of applied $\mathrm{P}$ and the chemically estimated supply of $\mathrm{P}$ from the soils were examined graphically by $\mathrm{RCY} / \mathrm{P}_{\mathrm{Ac}}$ plots.

\section{Results and discussion}

\section{Yields at eight sites}

A summary of the cumulative yields presented in Fig. 2 shows that the yield responses were relative small and not found on soils which had high soil test $\mathrm{P}$ values measured with $\mathrm{P}_{\mathrm{Ac}}$. In addition to the chemically estimated availability of $\mathrm{P}$, other prop- erties of the individual soils, crop species and weather conditions also had an impact on the effects of applied P. The relatively modest yields and their small responses to $\mathrm{P}$ fertilisation on the physically favourable loam soil 2 in Pälkäne resulted from bad lodging of oats in 1979 and barley in 1983 (cultivar Otra) and 1987 (Silja). In 1983 and 1987 the insignificant response was not larger than $150 \mathrm{~kg} \mathrm{ha}^{-1}$, but in a stiffer barley cultivar (Pomo) grown in 1978 and 1980 the significant yield effect of $\mathrm{P}$ was $450 \mathrm{~kg} \mathrm{ha}^{-1}$.

The loam soil 6 in Kokemäki which was rich in organic matter did not respond to $\mathrm{P}$ fertilisation in spite of a medium $\mathrm{P}_{\mathrm{Ac}}$ value. The early growth was sometimes visually weaker in the control. Other chemical methods produced relatively higher $\mathrm{P}$ values in agreement with the good bioavailability of $\mathrm{P}$ (Table 2). The winter cereals grown on the rich but acid soil 7 produced generally rather mod-

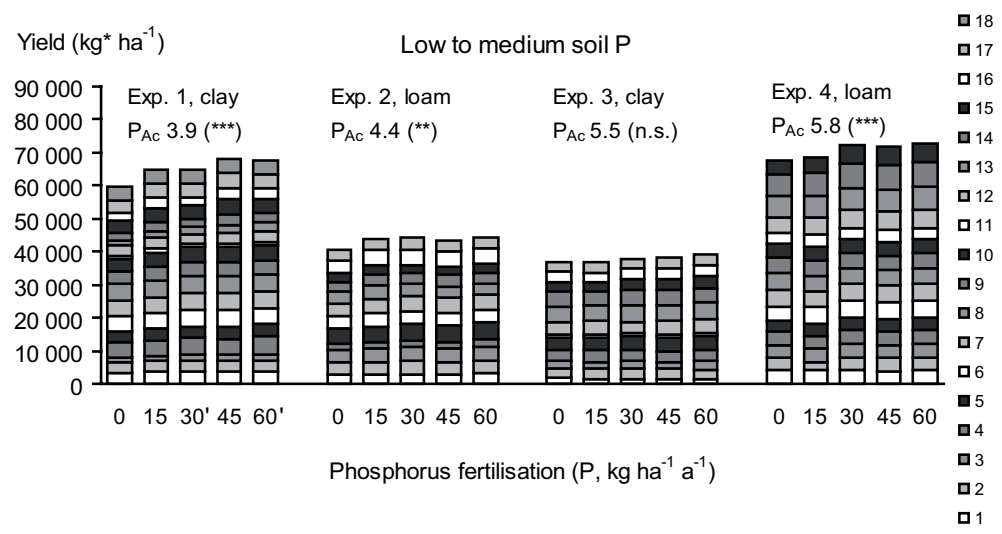

Yield $\left(\mathrm{kg}^{*} \mathrm{ha}^{-1}\right)$

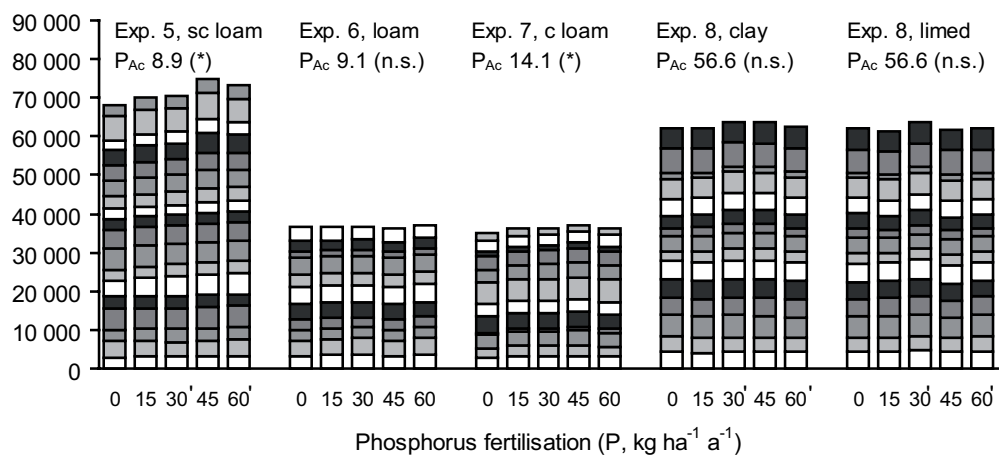

Fig. 2. Effects of different amounts of repeated annual P fertilisation on cumulative yield on eight clay and loam soils in southern and western Finland over 12-18 successive seasons. White sub-bars from bellow indicate the 1 st, 6th, 11th and 16th years. 30' and 60' indicate residual effects of previous fertilisation in the last six years. Yield unit $\left(\mathrm{kg}^{*}\right)=0.5$ $\mathrm{kg}$ rapeseed, $1.0 \mathrm{~kg}$ cereal grain or 1.0 feed units of grass equivalent to $1.0 \mathrm{~kg}$ barley grain. Asterisks $(*, * *, * * *)$ indicate significant effect of $\mathrm{P}$ fertilisation $(\mathrm{F})$ at $\mathrm{P}=0.05,0.01$ and 0.001 , respectively, n.s = not significant. 
est yields, particularly in relation to the total amounts of $\mathrm{N}$ applied at sowing and in spring (Table 3).

The clay soil of experiment 8 in Jokioinen had been used for growing of sugar beet and it was therefore limed and fertilised heavily (Table 2). As typical Finnish clay, its aggregate structure resisted gentle rain but not heavy showers, after which the soil mass was exposed to rapid evaporation and hardening. When that occurred at a critical time during the early season, the crop suffered from poor rooting and drought. The high concentration of extractable $\mathrm{P}$ in the surface soil supplied $\mathrm{P}$ abundantly when moist, resulting in exceptionally high concentrations of $\mathrm{P}$ in the grain crop $(0.50 \%$ in dry matter, usual $0.40 \%$ ). However, drying of the enriched surface soil and the poor availability of $\mathrm{P}$ in the subsoil (Saarela et al. 1995, 2003) caused temporary $\mathrm{P}$ deficiencies in the crops during long dry periods.

The importance of soil depth enriched with nutrients was demonstrated in the UK (McEwen and Johnston 1979). Finnish soils are saturated with water in the spring, but a thin layer of the clay surface is rapidly dried through evaporation. The drying front remains sharp during the early summer and reaches the bottom of the enriched plough layer in the middle of June, during a critical stage in spring cereals (Elonen and Kara 1972, Saarela et al. 2000). Each additional centimetre in the depth of the clay soil enriched with $\mathrm{P}$ prolongs the supply of $\mathrm{P}$ from the surface soil by about one day during the dry periods common in Finland during early summer. The theoretical benefits of deepening the soil enriched with $\mathrm{P}$ were confirmed experimentally by field studies (Saarela et al. 2000).

\section{Yield variation at three sites}

The heavy clay soil of experiment 1 in Mietoinen had relatively low content of organic $\mathrm{C}$ and extractable $\mathrm{P}$ and a nearly neutral $\mathrm{pH}$ (Table 2 ), which is considered optimal for most crops. The small grain yields of barley in 1979 and of spring wheat in 1987 did not depend on P fertilisation (Fig. 3). The short barley cultivar (Eero) suffered from the dryness of early summer in 1979 and the spring wheat in 1987 from the extremely cold and rainy season, which prevented its normal ripening. In contrast, in the years 1989 and 1990, the modest yields of the same crops responded relatively well to $\mathrm{P}$ fertilisation. An increasing trend of the yield differences is obvious on this soil. The annual application of $15 \mathrm{~kg} \mathrm{P} \mathrm{ha}^{-1}$ and the final $\mathrm{P}_{\mathrm{Ac}} 3.6 \mathrm{mg}$ $\mathrm{dm}^{-3}$ were insufficient for maximal yields of barley, spring wheat and oilseed rape (yield unit 0.5 $\mathrm{kg} \mathrm{ha}^{-1}$ ).

The Litorina soil of experiment 4 in Ylistaro had a low concentration of water extractable $\mathrm{P}$ and a strong capacity to sorb applied P (Table 2), but its subsoil appeared to be relatively rich in $\mathrm{P}$ (Saarela et al. 2003). Typical for Litorina profiles, the soil was well drained and physically favourable for rooting. Oats grown continuously in the first nine years produced stable yields and responded to $\mathrm{P}$ fertilisation only in the fifth and sixth years, 1981 and 1982, which were cold during the critical early development in June (Table 4). In the warm season of the tenth year (1986) for an unknown reason, barley produced slightly but statistically significantly smaller grain yields with $\mathrm{P}$ fertilisation than without.

A probable reason for the good performances of oats in relation to the soil test $\mathrm{P}$ values of the surface soil at site 4 was the contribution of the subsurface layers in supplying P to crops. In accordance with the low concentration of water extractable $\mathrm{P}$ in the soil, pot-grown barley and oats produced almost no grain on the surface soil if no P was applied (Saarela 1992, Saarela et al. 2003). During the last five of the 15 years a continuous positive response to $P$ fertilisation was measured at site 4 (Fig. 3). The rich but acid subsoil seemed to be less beneficial for barley and timothy. The small yield response in the non-mycorrhizal plant turnip rape in 1987 suggested that the symbiotic mechanism was not exceptionally important in this soil.

The rather acid loam soil in experiment 5 was a mixture of clay and sand with only $11 \%$ fine silt $(2-20 \mu \mathrm{m})$. The soil was physically fairly favourable for growth, but the low content of organic matter obviously weakened its drought resistance. This soil had a high content of oxalate extractable 
Vol. 15 (2006): 106-123.

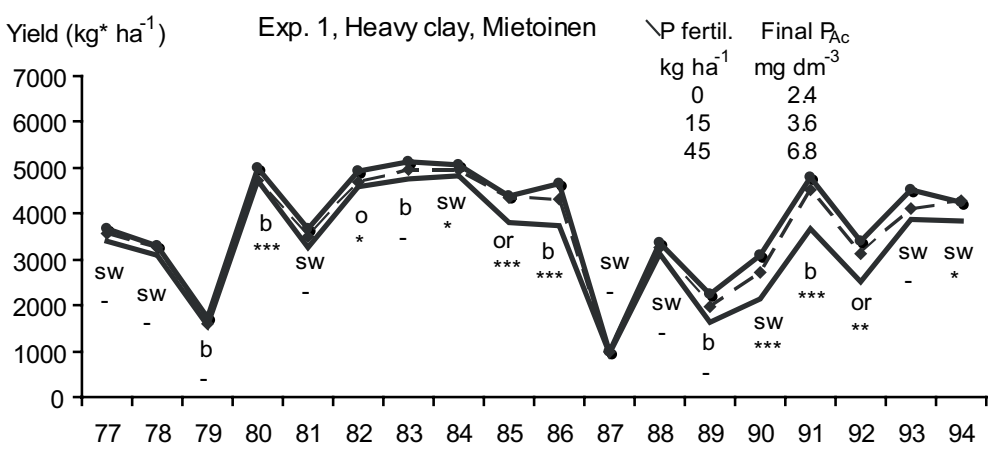

Yield $\left(\mathrm{kg}^{*} \mathrm{ha}^{-1}\right)$

Exp. 4, loam rich in OM, Ylistaro
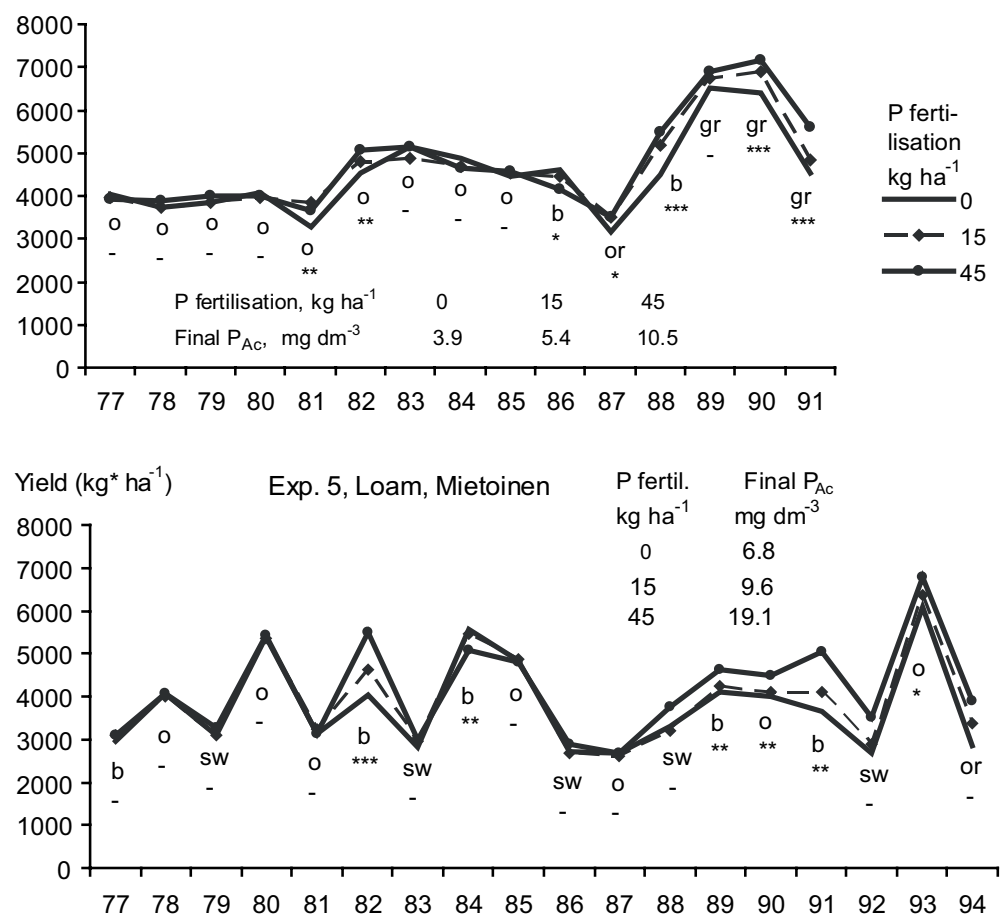

Fig. 3. Annual variation in yields with three amounts of repeated $\mathrm{P}$ fertilisation on three soils. Yield unit $(\mathrm{kg} *)=0.5 \mathrm{~kg}$ rapeseed, $1.0 \mathrm{~kg}$ cereal grain or 1.0 feed units of grass equivalent to $1.0 \mathrm{~kg}$ barley grain. $\mathrm{sw}=$ spring wheat, $\mathrm{b}=$ barley, $\mathrm{o}=$ oats, or $=$ oilseed rape. Asterisks $(*, * *, * * *)$ indicate significant effect of $P$ fertilisation (F) at $\mathrm{P}=0.05,0.01$ and 0.001 , respectively, $-=$ not significant.

Fe in relation to $\mathrm{Al}$ (Hartikainen 1989), which is more typical for more fine-textured soils (Kaila 1963). The high Fe/Al ratio and low content of organic matter were possible reasons for the efficient improvement of the availability of $\mathrm{P}$ by liming as typical for clay soils (Saarela et al. 2000, 2003). This soil performed relatively well in the pot experiment, not only with liming but also without.

Grain yields and their responses to P fertilisation varied widely and irregularly at site 5 (Fig. 3).
Sharp peaks occurred with the moderately acidsensitive barley cultivars grown in the cool and dry seasons in 1982 (Suvi) and 1991 (Ida). As a more acid-tolerant crop, oats performed relatively well in this acid soil. As the mean of six years, RCY was $96 \%$ in oats, but $90 \%$ in barley and spring wheat in eleven years. No increases in oat yields by applied $\mathrm{P}$ were found until the fourteenth experimental year in 1990 (Fig. 3). The highest grain yield in this site was obtained in the 17 th year 
Saarela, I. et al. Effects of repeated P fertilisation on field crops: clay and loam soils

when $192 \mathrm{~kg} \mathrm{P} \mathrm{ha}^{-1}$ had been removed from the soil by the previous sixteen crops. Then the grain yield grown without $\mathrm{P}$ fertilisation was $6.08 \mathrm{t} \mathrm{ha}^{-1}$ and contained $20.7 \mathrm{~kg} \mathrm{P} \mathrm{ha}^{-1}$.

\section{Effects of residual and freshly applied $P$}

The yield responses to $\mathrm{P}$ fertilisation were roughly similar for the first two periods of six years, while sharp drops in the RCY values were found later on soils 1, 4 and 5 which contained low or medium amounts of extractable $\mathrm{P}$ (Table 5). The residual effects of previous $P$ fertilisation studied on soils 1 and 5 in years $13-18$ can be directly compared to the effects of continuous P fertilisation. During the final three years the earlier treatments were continued with the NK fertilisation and the NPK fertilisation formed an additional factor. As mean of soils 1 and 5 for the years $13-18$, the yield response to continuous fertilisation with $45 \mathrm{~kg} \mathrm{P} \mathrm{ha}^{-1}$ was $800 \mathrm{~kg} \mathrm{ha}^{-1}$. As per cent of this, the residual effect of annual $\mathrm{P}$ application repeated 12 times was 30 and $68 \%$ with the P rates 30 and $60 \mathrm{~kg} \mathrm{ha}^{-1}$, respectively. The corresponding effect of continuous fertilisation with $15 \mathrm{~kg} \mathrm{P} \mathrm{ha}^{-1}$ was $50 \%$ or 400 $\mathrm{kg} \mathrm{ha}^{-1}$.

A summary of the results obtained with similar amounts of $\mathrm{N}$ and 0 or $20 \mathrm{~kg} \mathrm{P} \mathrm{ha}{ }^{-1}$ with $\mathrm{NK}$ and NPK is presented in Fig. 4 as means of the experiments 1 and 5. The NPK fertiliser was almost equally efficient with the residuals of 30 and $60 \mathrm{~kg}$ $\mathrm{P} \mathrm{ha}^{-1}$ as with the control treatment. The compound fertiliser produced maximum yields with residual $\mathrm{P}$ applied at $60 \mathrm{~kg} \mathrm{ha}^{-1}$ but not at $30 \mathrm{~kg} \mathrm{ha}^{-1}$. Continuous use of $45 \mathrm{~kg} \mathrm{ha}^{-1}$ sufficed for maximum yields without any supplement. The poor effect of NPK together with the $15 \mathrm{~kg} \mathrm{P} \mathrm{ha}^{-1}$ applied as superphosphate was possibly an exceptional result, which contradicts with the corresponding responses on the sandy soils 11 and 15 of this project (Saarela et al. 1995).

The decline of yields with large amounts of residual $\mathrm{P}$ showed the importance of continuous $\mathrm{P}$ fertilisation for sustainable plant production even in relatively rich soils. After twelve years the total amounts of $\mathrm{P}$ applied with the rates 30 and $60 \mathrm{~kg}$ ha $^{-1}$ were 360 and $720 \mathrm{~kg} \mathrm{ha}^{-1}$, and after fifteen years the residuals had aged for three to fifteen years. Since the amounts of $P$ removed with the harvested crops varied little with $\mathrm{P}$ fertilisation, the corresponding differences in $\mathrm{P}$ balance ( $\mathrm{P}$ fertilisation minus $\mathrm{P}$ removal in crops) between these treatments and the control were almost as large as the difference in P fertilisation or 350 and $710 \mathrm{~kg}$ $\mathrm{ha}^{-1}$. In relation to the total amounts of residual $\mathrm{P}$ accumulated in the soil, the yield responses were rather small in the final years of the experiments. On the other hand, normal annual fertilisation did not entirely compensate for the deficient supply of $\mathrm{P}$ from the soils impoverished by reduced fertilisation.

The short-term efficiency of the NPK-P, applied in accordance with general Finnish farming practice, was possibly poorer than usual because of the dry seasons. The loose fertiliser rows may dry up rapidly and remain practically rootless for weeks, and then the $\mathrm{P}$ of the fertiliser is almost totally unavailable. The normal placement of $\mathrm{P}$, about $8 \mathrm{~cm}$, may be too deep in wet and cold soils, as also found by Dibb et al. (1990). Roots should grow close to the fertiliser rows, because applied $\mathrm{P}$ remains within a $25 \mathrm{~mm}$ wide band for several months (Saarela and Saarela 2000). Rolling the whole soil surface or compacting the fertiliser rows with press wheels has been found to facilitate their rapid rooting and promote $\mathrm{P}$ uptake and growth during the dry early seasons typical in Finland.

\section{Yield response and soil $P_{A c}$}

The supply of nutrients to crops is universally estimated on the basis of chemical soil tests. The $\mathrm{P}$ values determined by the Finnish acid ( $\mathrm{pH} 4.65)$ ammonium acetate method $\left(\mathrm{P}_{\mathrm{Ac}}\right)$ used since the 1950 s, have predicted the availability of soil $\mathrm{P}$ fairly well in moderately and weakly acid soils (Keränen et al. 1963, Saarela 2002). In this study, each soil was tested every third seasons during the experimental period (Saarela et al. 2004). The $\mathrm{P}_{\mathrm{Ac}}$ values are presented as means of the whole experimental period and the two (1-6 years and 7-12 
Vol. 15 (2006): 106-123.

Table 5. Soil test $\mathrm{P}$ values $\left(\mathrm{P}_{\mathrm{Ac}}, \mathrm{mg} \mathrm{dm} \mathrm{dm}^{-3}\right)$ and relative yields (RY) during two or three periods at each site and the means of two groups of soils with "low" (sites $1-4)$ and "high" (sites $5-8)$ initial levels of $\left(\mathrm{P}_{\mathrm{Ac}}\right)$. Values with residual $\mathrm{P}$ after withdrawn $\mathrm{P}$ fertilisation are presented in parantheses.

\begin{tabular}{|c|c|c|c|c|c|c|c|c|c|c|c|c|c|}
\hline \multirow{2}{*}{$\begin{array}{l}\text { Site } \\
\text { No }\end{array}$} & \multirow{2}{*}{$\begin{array}{l}\text { Crop } \\
\text { years }\end{array}$} & \multicolumn{5}{|c|}{ Soil $\mathrm{P}_{\mathrm{Ac}}$ by $\mathrm{P}$ rates $\left(\mathrm{kg} \mathrm{ha}^{-1} \mathrm{a}^{-1}\right)$} & \multicolumn{5}{|c|}{ RY by $\mathrm{P}$ rates $\left(\mathrm{kg} \mathrm{ha}^{-1} \mathrm{a}^{-1}\right)$} & \multirow{2}{*}{$\begin{array}{l}\text { Relative value } \\
100=\mathrm{kg}^{1)} \mathrm{ha}^{-1}\end{array}$} & \multirow{2}{*}{$\begin{array}{l}\text { Sign }^{3)} \\
\text { effects }\end{array}$} \\
\hline & & 0 & 15 & 30 & 45 & 60 & 0 & 15 & 30 & 45 & 60 & & \\
\hline \multirow[t]{4}{*}{1} & $1-6$ & 3.1 & 3.6 & 4.6 & 4.4 & 5.4 & 90 & 94 & 99 & 98 & 100 & 3770 & 3 \\
\hline & $7-12$ & 3.1 & 4.0 & 5.6 & 6.0 & 7.5 & 91 & 98 & 98 & 100 & 100 & 3910 & 4 \\
\hline & $13-18$ & 2.3 & 3.6 & (4.3) & 6.7 & (6.9) & 78 & 93 & (87) & 100 & (96) & 3710 & 4 \\
\hline & $1-18$ & 2.8 & 3.7 & (4.9) & 5.7 & (6.6) & 87 & 95 & (98) & 100 & $(100)$ & 3800 & 11 \\
\hline \multirow[t]{3}{*}{2} & $1-6$ & 3.9 & 4.6 & 4.1 & 4.6 & 4.3 & 93 & 98 & 101 & 98 & 100 & 3670 & 3 \\
\hline & $7-12$ & 3.0 & 4.5 & 5.9 & 7.0 & 7.8 & 92 & 103 & 100 & 100 & 100 & 3660 & 3 \\
\hline & $1-12$ & 3.5 & 4.5 & 5.0 & 5.8 & 6.1 & 93 & 100 & 101 & 99 & 100 & 3670 & 6 \\
\hline \multirow[t]{3}{*}{3} & $1-6$ & 4.7 & 5.4 & 6.8 & 5.8 & 6.5 & 94 & 97 & 100 & 98 & 100 & 2530 & 2 \\
\hline & $7-12$ & 5.8 & 6.5 & 8.3 & 9.0 & 11.1 & 94 & 93 & 96 & 99 & 100 & 3910 & 0 \\
\hline & $1-12$ & 5.3 & 5.9 & 7.6 & 7.4 & 8.8 & 94 & 95 & 98 & 99 & 100 & 3220 & 2 \\
\hline \multirow[t]{4}{*}{4} & $1-6$ & 5.0 & 5.2 & 5.9 & 6.0 & 6.7 & 95 & 98 & 102 & 99 & 100 & 4130 & 2 \\
\hline & $7-12$ & 4.6 & 5.9 & 6.9 & 7.9 & 9.2 & 98 & 99 & 100 & 100 & 100 & 4600 & 3 \\
\hline & $13-15$ & 3.6 & 5.1 & 6.8 & 8.5 & 10.1 & 88 & 93 & 97 & 100 & 100 & 7860 & 2 \\
\hline & $1-15$ & 4.6 & 5.5 & 6.5 & 7.2 & 8.3 & 95 & 97 & 100 & 100 & 100 & 5060 & 7 \\
\hline $1-4$ & $1-18$ & 3.9 & 4.8 & $(6.0)$ & 6.5 & (7.4) & 92 & 97 & (99) & 99 & (100) & 3980 & $26 / 57$ \\
\hline \multirow[t]{4}{*}{5} & $1-6$ & 7.7 & 8.6 & 8.7 & 10.6 & 10.1 & 93 & 96 & 97 & 99 & 100 & 4110 & 1 \\
\hline & $7-12$ & 7.1 & 8.7 & 9.9 & 13.2 & 14.4 & 98 & 97 & 99 & 100 & 100 & 3690 & (1) \\
\hline & $13-18$ & 6.6 & 9.2 & (9.4) & 16.4 & (13.0) & 82 & 88 & (87) & 100 & (93) & 4720 & 4 \\
\hline & $1-18$ & 7.1 & 8.8 & $(9.7)$ & 13.4 & (12.5) & 91 & 94 & (97) & 100 & (98) & 4180 & 5 \\
\hline \multirow[t]{3}{*}{6} & $1-6$ & 9.1 & 9.2 & 8.8 & 9.8 & 9.5 & 98 & 100 & 100 & 98 & 100 & 3380 & 0 \\
\hline & $7-12$ & 7.8 & 8.9 & 9.9 & 11.1 & 12.8 & 103 & 99 & 100 & 99 & 100 & 3050 & 0 \\
\hline & $1-12$ & 8.5 & 9.0 & 9.3 & 10.4 & 11.0 & 100 & 100 & 100 & 99 & 100 & 3340 & 0 \\
\hline \multirow[t]{3}{*}{7} & $1-6$ & 12.5 & 13.3 & 13.8 & 14.4 & 15.3 & 92 & 97 & 99 & 102 & 100 & 2930 & 0 \\
\hline & $7-12$ & 10.2 & 11.7 & 12.8 & 14.5 & 17.0 & 95 & 97 & 99 & 100 & 100 & 3200 & 2 \\
\hline & $1-12$ & 11.3 & 12.5 & 13.3 & 14.5 & 16.1 & 93 & 97 & 99 & 101 & 100 & 3060 & 2 \\
\hline \multirow[t]{4}{*}{8} & $1-6$ & 55.6 & 66.4 & 58.6 & 72.0 & 52.6 & 100 & 99 & 101 & 101 & 100 & 4630 & 0 \\
\hline & $7-12$ & 37.4 & 47.7 & 49.4 & 56.7 & 49.0 & 95 & 97 & 102 & 103 & 100 & 4690 & 0 \\
\hline & $13-15$ & 30.9 & 41.2 & (39.0) & 59.3 & $(39.5)$ & 99 & 96 & (99) & 100 & (102) & 4570 & 0 \\
\hline & $1-15$ & 43.4 & 53.9 & (51.1) & 63.3 & (48.6 & 98 & 98 & (101) & 101 & (100) & 4640 & 0 \\
\hline \multirow[t]{4}{*}{$8 \mathrm{~L}^{2)}$} & $1-6$ & 57.5 & 51.2 & 71.3 & 58.5 & 73.2 & 99 & 100 & 103 & 99 & 100 & 4540 & 0 \\
\hline & $7-12$ & 46.9 & 44.3 & 69.3 & 63.5 & 70.2 & 105 & 99 & 104 & 101 & 100 & 4570 & 0 \\
\hline & $13-15$ & 42.5 & 40.3 & $(61.5)$ & 63.3 & $(63.6)$ & 94 & 95 & (98) & 100 & (98) & 4670 & 1 \\
\hline & $1-15$ & 50.2 & 46.2 & (69.7) & 61.5 & $(70.3)$ & 100 & 99 & (103) & 100 & (100) & 4580 & 1 \\
\hline $5-8$ & $1-18$ & 24.8 & 26.9 & (31.5) & 33.8 & (32.9) & 96 & 97 & (100) & 100 & (100) & 4040 & $8 / 71$ \\
\hline \multirow[t]{4}{*}{$1-8$} & $1-6$ & 17.7 & 18.6 & 20.3 & 20.7 & 20.4 & 95 & 98 & 100 & 99 & 100 & 3770 & $11 / 54$ \\
\hline & $7-12$ & 14.1 & 15.9 & 20.0 & 21.2 & 22.3 & 97 & 98 & 100 & 100 & 100 & 3940 & $12 / 53$ \\
\hline & $13-15$ & 13.5 & 16.0 & (19.6) & 25.3 & $(28.1)$ & 86 & 92 & (96) & 100 & $(100)$ & 4850 & $11 / 21$ \\
\hline & $1-18$ & 15.5 & 17.1 & (20.1) & 21.6 & $(22.0)$ & 95 & 97 & (100) & 100 & (100) & 4010 & $34 / 128$ \\
\hline
\end{tabular}

1) $1.0 \mathrm{~kg}$ grain, $0.5 \mathrm{~kg}$ rapeseed or 1.0 feed units of grass equivalent to one $\mathrm{kg}$ barley grain

2) initial liming with $10 \mathrm{tha}^{-1}$ ground limestone in 1980

${ }^{3)}$ number of years with significant effect at $\mathrm{P}=0.05$ (negative effects in parentheses) 
Fig. 4. Effects of continuous (years 1-18), residual (withdrawn from year 13) and annual $P$ fertilisation $\left(20 \mathrm{~kg} \mathrm{ha}^{-1}\right)$ on yields in crop years 16-18, means from sites 1 and 5. Error bars are based on treatment means at each site and show the confidence intervals at $\mathrm{P}=0.05$.

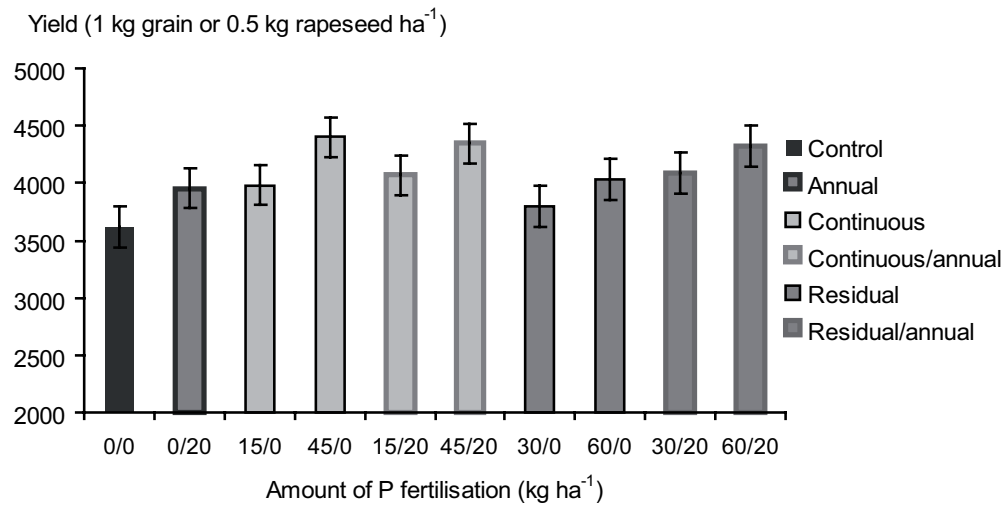

years) or three (13- years) periods together with the corresponding RY values (Table 5).

The results of other field studies on clay and loam soils (Table 1) were summarised with the respective data of this study (Table 5). The combined data allows the relationships of the yield responses and the $\mathrm{P}_{\mathrm{Ac}}$ values for different types of soil to be examined (Fig. 5). The sugar beet yields reported by Brummer (1959) show the essential differences between crops in $\mathrm{P}$ requirement. The large yield responses of sugar beet at the medium level of $\mathrm{P}_{\mathrm{Ac}}$ are in agreement with the Swedish results obtained in sugar beets and other crops grown in rotation in the same plots (Carlgren and Mattsson 2001).

In agreement with earlier studies (Sippola 1980, Saarela 1992), the $\mathrm{P}_{\mathrm{Ac}}$ value required for optimal yields depended on the $\mathrm{pH}$ of the soil (Fig. 5). Exceptionally high $\mathrm{pH}$, at which the acetate method produces too high and unreliable values (Saarela 1992, Jaakkola et al. 1997) was associated with a large response to $\mathrm{P}$ fertilisation. Large responses to applied $\mathrm{P}$ were frequently measured at low $\mathrm{pH}$ values, and even the moderately weak acidity common in Finnish soils (Mäkelä-Kurtto and Sippola 2002) was detrimental. The rather strongly acid soil 2 in Pälkäne ( $\mathrm{pH}$ 5.6), which appeared less toxic than typical at this $\mathrm{pH}$ and suffered from lodging, was probably untypical and should not be extrapolated for cereals other than oats. All the other acid mineral soils having a normal content of organic matter produced smaller
$\mathrm{RY}$ values than were obtained at optimal $\mathrm{pH}$. In strongly acid mineral soils, extractable $\mathrm{P}$ was poorly available even to oats (Saarela 1992). The detrimental effects of low $\mathrm{pH}$ values on $\mathrm{P}$ availability are probably largely biological and caused by dissolved aluminium.

All the Litorina soils plotted in Fig. 5 were better sources of $\mathrm{P}$ than the glacial soils. The high content of organic matter in the surface layer of the inherently deep soils was a possible reason for their good supply of P. However, the results of pot experiments and field studies from site 4 and other soils emphasise the importance of the lower part of soil profile. Deepening and diluting a glacial clay by deep ploughing improved the availability of $\mathrm{P}$ during dry periods and gave additional evidence of the role of the depth of the enriched soil (Table 1).

In the present study, the estimated optimal amount of repeated $\mathrm{P}$ fertilisation increased after twelve experimental years because of the sharp increase of the yield responses. The sharp decrease of RY with decreasing $\mathrm{P}_{\mathrm{Ac}}$ (Fig. 5) and the changes of these values during the study period agreed fairly well at site 1 (Table 5) and also in the two soils studied by Yli-Halla (1989) (ref. 7 in Table 1). At site 4 the large final yield effect of $\mathrm{P}$ fertilisation originated from the more requiring crops, barley and timothy in stead of oats (Table 3 ), and no significant changes in the responses were found in the soils 2 and 3 which were rather low in $\mathrm{P}_{\mathrm{Ac}}$. The decline of barley yields caused by insufficient $\mathrm{P}$ 
Vol. 15 (2006): 106-123.

fertilisation appeared to be rather sharp in some acid silty and sandy soils (Saarela et al. 1995) and not entirely explained by chemical soil tests.

The results from clay and loam soils summarised in Fig. 5 show the typical relationships between RY and the soil $\mathrm{P}_{\mathrm{Ac}}$ value fairly exactly for sufficiently limed soils. The fundamental reason for the good fit is the primary importance of the intensity factor of soil $\mathrm{P}$ status for the supply of $\mathrm{P}$ from Finnish mineral soils (Saarela 1992) and a sufficient reliability of the acetate method in indicating it. The intensity character of the acetate method was shown by a close correlation of the $\mathrm{P}_{\mathrm{Ac}}$ values with water extractable $\mathrm{P}$ (Uusitalo and Jansson 2002). In recent unpublished studies the values of $\mathrm{P}_{\mathrm{Ac}}$ and water extractable $\mathrm{P}$ correlated especially closely in the weakly acid fine-textured soils in which Fe is a major sorption agent (Kaila 1963).

A good dependence between soil test $\mathrm{P}$ values and yield responses requires that both of them are reproducible and reliable parameters, and a high correlation coefficient requires that the supply of $\mathrm{P}$ to crops is insufficient. The relatively precisely determined and narrow response range to soil $\mathrm{P}_{\mathrm{Ac}}$ at optimum $\mathrm{pH}$ is largely attributable to the long-term yield responses. As shown by Munk and Rex (1990), the yield effects obtained by short-term field experiments are not reliable indications of the availability of $\mathrm{P}$ in the soil and the optimal amount of long-term $\mathrm{P}$ fertilisation. When the $\mathrm{pH}$ is optimal, the acetate method appeared to be suitable even for precision fertilisation of $\mathrm{P}$, while the same method is inaccurate at too low and too high $\mathrm{pH}$.

\section{Sufficient level of $P_{A c}$}

At some sites the yield responses to $\mathrm{P}$ fertilisation were large enough to allow the requirement of $\mathrm{P}$ fertilisation and the corresponding $\mathrm{P}_{\mathrm{Ac}}$ values to be derived from the response curves. As much as 45 $\mathrm{kg} \mathrm{P} \mathrm{ha}{ }^{-1}$ and a final $\mathrm{P}_{\mathrm{Ac}}$ value of $19.1 \mathrm{mg} \mathrm{dm}^{-3}$ was required for maximum yields in the acid loam at site 5 . In the acid clay loam in Vihti (Yli-Halla 1989), $30 \mathrm{~kg} \mathrm{P} \mathrm{ha}^{-1}$ was sufficient, though the final $\mathrm{P}_{\mathrm{Ac}}$ value was not higher than $4.3 \mathrm{mg} \mathrm{dm}^{-3}$. Large amounts of $\mathrm{P}$ were required at optimal $\mathrm{pH}$ in soil 1 because of its low initial $\mathrm{P}_{\mathrm{Ac}}$ value and strong buffering for $\mathrm{P}$ (Fig. 1, Table 5), but the final $\mathrm{P}_{\mathrm{Ac}}$ value was not higher than $6.7 \mathrm{mg} \mathrm{dm}^{-3}$ at $45 \mathrm{~kg} \mathrm{P} \mathrm{ha}^{-1}$ which was sufficient. The best effect with the lowest rate of $\mathrm{P}\left(15 \mathrm{~kg} \mathrm{ha}^{-1}\right)$ was obtained in the loam soil at site 2, where maximum yield was achieved at $\mathrm{P}_{\mathrm{Ac}} 4.5 \mathrm{mg} \mathrm{dm}^{-3}$.

The yields obtained with different rates of repeated $\mathrm{P}$ fertilisation (Fig. 2, Table 5) indicate that the amounts of $\mathrm{P}$ similar to those of the harvested yield do not suffice for maximal yields if the $\mathrm{P}_{\mathrm{Ac}}$ value is low and the yield responses large. This statement is true even though the P fertiliser was applied by the placement method. The increased mycorrhizal contribution studied in soil 1 (Kahiluoto et al. 2001) also seemed to be insufficient to compensate for the declining availability of $\mathrm{P}$ as detected by the chemical test. Soil test P (STP) values that are too low should be increased by applying larger amount of $\mathrm{P}$ than is removed with the harvested crops and fixed in the soil. Adequate $\mathrm{P}$ status should then be maintained by continuous fertilisation.

Replenishment of the P taken up by the crop and lost by fixation probably suffice for optimal long-term yields when the control treatment produces about $95 \%$ of the maximum yield obtained with large amounts of $\mathrm{P}$ fertilisation $(\mathrm{RCY}=95 \%)$. The loss of extractable $\mathrm{P}$ caused by fixation to the soil in the $0.23 \mathrm{~m}$ deep plough layer was variable and slow at low level of $\mathrm{P}_{\mathrm{Ac}}$, on average $6 \mathrm{~kg} \mathrm{P} \mathrm{ha}^{-1}$ at $\mathrm{P}_{\mathrm{Ac}} 5.0 \mathrm{mg} \mathrm{dm}^{-3}$ (Saarela at al. 2004). Cereal grain contains about $3.5 \mathrm{~kg} \mathrm{P}$ in a tonne or $14 \mathrm{~kg}$ in $4 \mathrm{t}$ (Saarela et al. 1995). Cereal straw contains about $6 \mathrm{~kg} \mathrm{P} \mathrm{ha}^{-1}$ but is usually returned to the soil. The low leaching of $\mathrm{P}$ from Finnish soils has a negligible effect on soil $\mathrm{P}$ status. The annual requirement of $\mathrm{P}$ for maintaining adequate $\mathrm{P}$ status is thus $20 \mathrm{~kg} \mathrm{ha}^{-1}$ at the typical yield level of $4.0 \mathrm{t}$ ha $^{-1}$.

At optimal soil $\mathrm{pH}, \mathrm{RCY}$ was $95 \%$ at $\mathrm{P}_{\mathrm{Ac}} 5-7$ $\mathrm{mg} \mathrm{dm}^{-3}$ (Fig. 5). Deep Litorina soils and deepened glacial soils occurred in the lower end of this range and typical glacial clay and loam soils in the upper end. Values of $\mathrm{P}_{\mathrm{Ac}}$ which are one or two units higher than are sufficient by the common placement fertilisation may be required if the immediate ef- 
Fig. 5. Dependence of relative control yield, RCY (yield without $\mathrm{P}$ fertilisation divided by the yield with sufficient $\mathrm{P}$ fertilisation) on extractable soil P. Large markers denote current conventional cultivation methods and means of 11 or more crop years (Tables 1 and 5). Small markers present old results, residual periods or other short studies. Sugar beet yields from Brummer's (1959) study.
RCY (\%)

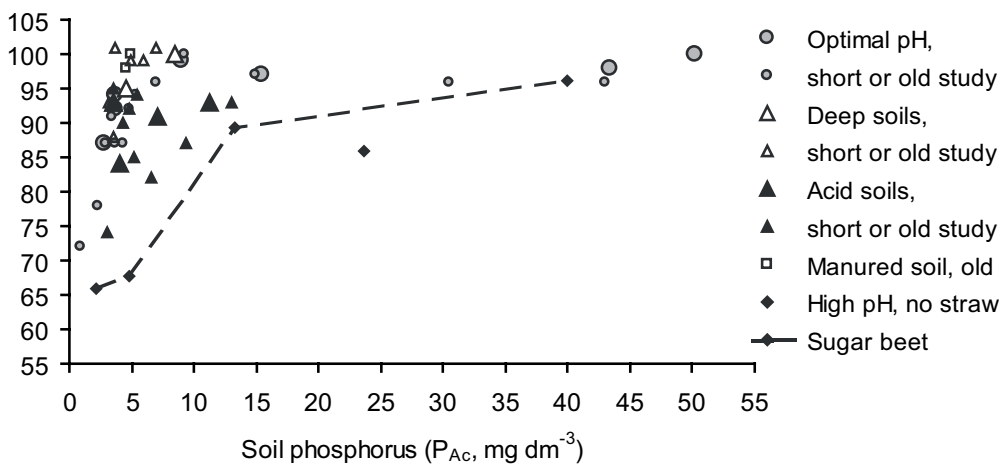

fect of applied $\mathrm{P}$ is impaired by less favourable date or method of fertilisation, as is typical for manure. Even a small difference in $\mathrm{P}_{\mathrm{Ac}}$ is significant according to the amounts of applied or removed $\mathrm{P}$ required to change the $\mathrm{P}_{\mathrm{Ac}}$ value. At $\mathrm{P}_{\mathrm{Ac}}$ 5.0 the mean buffer capacity derived from the field experiments was $133 \mathrm{~kg} \mathrm{P}^{-1}$ per unit $\mathrm{P}_{\mathrm{Ac}}$ (Saarela et al. 2004). The balance difference of $710 \mathrm{~kg} \mathrm{P} \mathrm{ha}^{-1}$ and final $\mathrm{P}_{\mathrm{Ac}}$ values of 2.4 and $5.2 \mathrm{mg} \mathrm{dm}^{-3}$ at the residual $\mathrm{P}$ rates 0 and $60 \mathrm{~kg} \mathrm{ha}^{-1}$ correspond to the buffer capacity of 710/2.8 $=254 \mathrm{~kg} \mathrm{ha}^{-1}$ per unit $\mathrm{P}_{\mathrm{Ac}}$.

The acid ammonium acetate soil test is a modification of the Morgan test, and the $\mathrm{P}_{\mathrm{Ac}}$ values of mineral soils closely correlate with the Morgan $\mathrm{P}$ values (Saarela et al. 2004). Because Morgan P is 0.7 times $\mathrm{P}_{\mathrm{Ac}}$, the critical $\mathrm{P}_{\mathrm{Ac}}$ range at optimal $\mathrm{pH}$ (5-7 $\left.\mathrm{mg} \mathrm{dm}^{-3}\right)$ is equal to the Morgan $\mathrm{P}$ range of $3.5-5 \mathrm{mg} \mathrm{kg}^{-1}$. These values correspond to the lower end of the optimal range of Morgan $\mathrm{P}$ in the north eastern parts of the United States, from 4 to $7 \mathrm{mg} \mathrm{kg}^{-1}$ (Jokela et al. 1998). In strongly acid glacial soils the adequate $\mathrm{P}_{\mathrm{Ac}}$ value was much higher and more variable.

\section{Application of results}

The soil test $\mathrm{P}$ values of cultivated Finnish soils were rapidly increasing during the 1970 s as a result of the general balance surplus of soil $\mathrm{P}$ caused by abundant fertilisation. The target range of $\mathrm{P}_{\mathrm{Ac}}$ for cereals and leys was $6-15 \mathrm{mg} \mathrm{dm}^{-3}$ in clay soils and $10-25 \mathrm{mg} \mathrm{dm}^{-3}$ in coarser soils including glacial loams. A large P surplus was assumed to be necessary to maintain sufficient $P$ availability in the acid soils of Finland. Small amounts of $\mathrm{P}$ were recommended up to the excessive $\mathrm{P}_{\mathrm{Ac}}$ value of 200 $\mathrm{mg} \mathrm{dm}{ }^{-3}$, and even in richer soils after a three years period of exhaustive cropping. The field experiments establish from the 1960s (Table 1) and the first results of this project summarised annually and reported in Finnish showed the possibilities to reduce the amounts of $\mathrm{P}$ fertilisation on the soils which had high $\mathrm{P}_{\mathrm{Ac}}$ values. Farmers were advised to check the amounts of applied P by means of soil tests.

The interpretation of the chemical soil test $\mathrm{P}$ values was revised on the basis of the Finnish report of these results (Saarela et al. 1995). The estimated optimal amounts of $\mathrm{P}$ are even maximal amounts allowed by the Agri-Environmental Program, which is an essential part of farm income (Koikkalainen and Lankoski 2004). The target range of $\mathrm{P}_{\mathrm{Ac}}$ for clay soils is $6-12 \mathrm{mg} \mathrm{dm}^{-3}$ for the clays rich in organic matter and 7-14 $\mathrm{mg} \mathrm{dm}^{-3}$ for the typical clays containing 6-3\% organic matter. For loam soils, which were ranked in the same category with silts and sands, the target range of $\mathrm{P}_{\mathrm{Ac}}$ is $10-18,12-20$ and $13-22 \mathrm{mg} \mathrm{dm}^{-3}$ at $>6,6-3$ and $<3 \%$ organic matter.

Within the target ranges the amount of annual $\mathrm{P}$ fertilisation, in $\mathrm{kg} \mathrm{ha}^{-1}$, is 10 for oats, 15 for wheat, rye and rapeseed, 18 for barley and 20 for 
Vol. 15 (2006): 106-123.

leys cut at least twice a season. These amounts are allowed for average yields and must be reduced with lower yields and may be increased with higher yields. As an environmentally important restriction in the fertilisation based on chemical soil testing, no fertiliser $\mathrm{P}$ is allowed to be used at $\mathrm{P}_{\mathrm{Ac}}>40$ $\mathrm{mg} \mathrm{dm}{ }^{-3}$ in clay soils and $>50 \mathrm{mg} \mathrm{dm}^{-3}$ in loam soils. The upper limits were derived from the equilibrium phosphate concentrations (EPC) determined for heavily enriched soils (Yli-Halla et al. 1997).

\section{Conclusions}

The level of soil $\mathrm{P}_{\mathrm{Ac}}$ which gives a long-term RCY value of $95 \%$ was considered to be a relevant basis for $\mathrm{P}$ fertilisation recommendations. At optimal soil $\mathrm{pH}$ this RCY value was achieved at $\mathrm{P}_{\mathrm{Ac}} 5-6 \mathrm{mg}$ $\mathrm{dm}^{-3}$ in the Litorina soils and in the well-aggregated deep glacial clays, and at $\mathrm{P}_{\mathrm{Ac}} 6-7 \mathrm{mg} \mathrm{dm}^{-3}$ in the typical glacial clays and loams. At this $\mathrm{P}_{\mathrm{Ac}}$ the application of an amount of $\mathrm{P}$ equal to that in the harvested crop will increase the relative yield from $95 \%$ to almost maximum in most years, when the fertiliser is applied by the common placement method. In other words, the P status of the soil is optimal at this level of $\mathrm{P}_{\mathrm{Ac}}$.

The narrow range of optimal $\mathrm{P}_{\mathrm{Ac}}$ established in this study resulted from two essential requirements: i) the acid ammonium acetate soil testing method was reliable in predicting the supply of $\mathrm{P}$ to crops from the moderately and weakly acid soils rich in sorption active $\mathrm{Fe}$, and ii) the yield responses which were integrated over the long study periods levelled the untypical results of individual years caused by variable weather conditions and other reasons. The different $\mathrm{P}$ requirements and yield responses of individual species and varieties were also partly levelled.

The optimal $\mathrm{P}_{\mathrm{Ac}}$ value $\left(5-7 \mathrm{mg} \mathrm{dm}^{-3}\right.$ ) correspond to the lower end of the present target range for clay soils, but is slightly lower than the present target for loam soils. In acid soils (pH 5.6-6.0 in mineral soils) the same target $\mathrm{P}_{\mathrm{Ac}}$ is probably suf- ficient for oats, but not for other crops grown without proper liming. In still more acid soils the availability of $\mathrm{P}$ is poor even for oats and other moderately acid-tolerant crops. The smaller apparent $\mathrm{P}$ requirement of oats obtained during the first years of this project was probably largely caused by the better tolerance to soil acidity of this crop and should not be extrapolated to adequately limed soils.

Acknowledgements. This research project was initiated by the late professor Paavo Elonen and conducted at the Soils and Environment unit in Jokioinen and at MTT's three research stations by local staff under local direction. The authors wish to thank Dr. h. c. Jaakko Köylijärvi for conducting several field experiments, Risto Tanni and Matti Ylösmäki for performing field experiments, Kerttu Hämäläinen and Katariina Saarela for handling the yields, Pekka Kivistö for soil analyses and all the colleagues who contributed to the field and laboratory studies and preparation of this paper. Appreciation for the chemical soil analyses is owed to Sten Engblom, SLU, Sweden, Leo Kevvai, ERIA, Estonia, Bernardo van Raij, IA, Brazil and Sjoerd van der Zee, WAU, the Netherlands.

\section{References}

Aura, E. 1978. Determination of available soil phosphorus by chemical methods. Journal of the Scientific Agricultural Society of Finland 50: 305-316.

Brummer, V. 1959. Lannoituksen vaikutuksesta sokerijuurikkaan satoon. Summary: Effect of fertilization on the yield of sugar beet. Acta Agralia Fennica 94: 201-239.

Carlgren, K. \& Mattsson, L. 2001. Swedish soil fertility experiments. Acta Agriculturae Scandinavica, Section B, Soil and Plant Science 51: 49-78.

Dibb, D.W., Fixen, P.E. \& Murpy, L.S. 1990. Balanced fertilisation with particular reference to phosphate: interaction of phosphorus with other inputs and management practices. Fertilizer Research 26: 29-52.

Egner, H., Riehm, H. \& Domingo, W.H. 1960. Untersuchungen über die chemische Bodenanalyse als Grundlage für die Beurteilung des Nährstoffzustandes der Böden. II. Chemische Extraktionsmethoden zur Phosphor- und Kaliumbestimmung. Kungliga Lantbrukshögskolans Annaler 26: 199-215.

Elonen, P. \& Kara, O. 1972. Sprinkler irrigation of clay soils in southern Finland. IV. The effect of repeated application of water and nitrogen fertilization on spring cereals. Journal of the Scientific Agricultural Society of Finland 44: 149-163.

Hakkola, H. 1998. Annual and storage application of phos- 
Saarela, I. et al. Effects of repeated P fertilisation on field crops: clay and loam soils

phorus to ley. Kungliga Skogs- och Lantbruksakademiens Tidskrift 137: 99-104.

Hartikainen, H. 1989. Effect of cumulative fertilizer dressings on the phosphorus status of mineral soils. Journal of Agricultural Science in Finland 61: 55-66.

Houba, V.J.G., Novozamsky, I., Lexmond, T.M. \& van der Lee, J.J. 1990. Applicability of the $0.01 \mathrm{M} \mathrm{CaCl}_{2}$ as a single extraction solution for the assessment of the nutrient status of soils and other diagnostic purposes. Communications in Soil Science and Plant Analysis 21: 2281-2290.

Jaakkola, A., Hakkola, H. Köylijärvi, J. \& Simojoki, P. 1977. Effect of liming on phosphorus fertilizer requirement in cereals and ley. Annales Agriculturae Fenniae 16: 207-219.

Jaakkola, A., Hartikainen, H. \& Lemola, R. 1997. Effect of fertilization on soil phosphorus in a long-term field experiment in Southern Finland. Agricultural and Food Science in Finland 6: 313-322.

Johnston, A.E. \& Poulton, P.R. 1992. The role of phosphorus in crop production and soil fertility: 150 years of field experiments at Rothamsted, United Kingdom. Proceedings of 4th International IMPHOS Conference. Ghent, Begium, p. 539-575.

Jokela, W.E., Magdoff, F.R. \& Durieux, R.P. 1998. Improved phosphorus recommendations using modified Morgan phosphorus and aluminum soil tests. Communications in Soil Science and Plant Analysis 29: 1739-1749.

Kahiluoto, H., Ketoja, E., Vestberg, M. \& Saarela, I. 2001. Promotion of AM utilization through reduced $\mathrm{P}$ fertilization. 2. Field studies. Plant and Soil 231: 65-79.

Kaila, A. 1963. Dependence of the phosphate sorption capacity on the aluminium and iron in Finnish soils. The Journal of the Scientific Agricultural Society of Finland 35: 165-177.

Keränen, T., Barkoff, E. \& Jokinen, R. 1963. Vergleich einiger für die Beurteilung des Nährstoffzustandes der Böden gebräuchlichen chemischen Analysenmethode. Annales Agricuturae Fenniae 2: 19-32.

Koikkalainen, K. \& Lankoski, J. 2004. Maatalouden ympäristötuen taloudellinen merkitys tukialueittain ja tuotantosuunnittain vuosina 2000-2001. Abstract: The economic impacts of agri-environmental support in different support areas and production lines in the years 2000-2001. In: Turtola, E. \& Lemola, R. Follow-up of the effectiveness of the Agri-Environmental Programme in Finland: results of sub-projects in 2000-2003. Agrifood Research Reports 59. p. 140-157.

Korkman, J. 1973. Sulphur status of Finnish cultivated soils. Journal of the Scientific Agricultural Society of Finland 45: 121-215.

Mäkelä-Kurtto, R. \& Sippola, J. 2002. Monitoring of Finnish arable land: changes in soils quality between 1987 and 1998. Agricultural and Food Science in Finland 11: 273-84.

McEwen, J. \& Johnston, A.E. 1979. The effects of subsoiling and deep incorporation of $P$ and $K$ fertilizers on the yield and nutrient uptake of barley, potatoes, wheat and sugar beet grown in rotation. Journal of Agricultural Science 92: 675-702.

Munk, H. \& Rex, M. 1990. Zur Eichung von Bodenuntersuchungsmethoden auf Phosphat. Summary: Notes on the calibration of phosphate soil testing methods. Agrobiological Research 43: 164-174.

Raij, B. van 1998. Bioavailable tests: Alternatives to standard soil extractions. Communications in Soil Science and Plant Analysis 29: 1553-1570.

Saarela, I. 1989. Growth of rye grass, barley and oats in soils amended with ashes of wood, bark, peat and coal. Annales Agriculturae Fenniae 28: 121-132.

Saarela, I. 1991. Wood, bark, peat and coal ashes as liming agents and sources of calcium, magnesium, potassium and phosphorus. Annales Agriculturae Fenniae 30: 375-388.

Saarela, I. 1992. A simple diffusion test for soil phosphorus availability. Plant and Soil 147: 115-126.

Saarela, I. 1998a. Ferric sewage sludge as a source of phosphorus to cereals in acid soils. In: 11th Word Fertilizer Congress of CIEC, Gent, Belgium, September 7 $-13,1997$. Volume 3, p. 81-87.

Saarela, I. 1998b. Problem soils in Finland require more phosphorus. Kungliga Skogs- och Lantbruksakademiens Tidskrift 137: 43-44.

Saarela, I. 2002. Phosphorus in Finnish soils in the 1900s with particular reference to the acid ammonium acetate soil test. Agricultural and Food Science in Finland 11: 257-271.

Saarela, I., Engblom, S., Kevvai, L., van Raij, B., Sippola, J. \& van der Zee, S. 1996. Present soil testing methods and new nutrient separation techniques as predictors of the responses of field crop yields to phosphorus fertilisation in Finland. Helsinki: Agro-food ry. p. P7. (in Finnish, the original English poster text available at MTT Agrifood Research Finland, Soils and Environment, FIN-31600 Jokioinen, Finland).

Saarela, I., Järvi, A., Hakkola, H. \& Rinne, K. 1995. Fosforilannoituksen porraskokeet 1977-1994. Summary: Phosphorus fertilizer rate trials 1977-1994. Maatalouden tutkimuskeskus, Tiedote 16/95. 94 p. + 14 app.

Saarela, I., Järvi, A., Hakkola, H. \& Rinne, K. 2003. Phosphorus status of diverse soils in Finland as influenced by long-term $P$ fertilisation. 1. Native and previously applied P at 24 experimental sites. Agricultural and Food Science in Finland 12: 117-132.

Saarela, I., Järvi, A., Hakkola, H. \& Rinne, K. 2004. Phosphorus status of diverse soils in Finland as influenced by long-term $P$ fertilisation. 2. Changes of soil test values in relation to $\mathrm{P}$ balance with references to incorporation depth of residual and freshly applied P. Agricultural and Food Science in Finland 13: 276-294.

Saarela, I., Kakkonen, K. \& Salo, Y. 2000. Savimaan fosforin satavuuden parantaminen runsaalla kalkituksella sekä ruokamullan ja fosforin syvämultauksella. Summary: Improving the availability of phosphorus in clay soils by heavy liming and by deep incorporation of topsoil and phosphorus. Maatalouden tutkimuskeskuksen julkaisuja. Sarja A. 51 p. +8 app.

Saarela, I. \& Saarela, K. 2000. Mapping spatial variation of diffusible soil $\mathrm{P}$ by in situ colouring in Fe-oxide paper. Communications in Soil Science and Plant Analysis 31: 2019-2025.

Salonen, M. 1963. Kiinteillä koekentillä suoritettujen uudismaan lannoituskokeiden tuloksia. Summary: On the 
Vol. 15 (2006): 106-123.

fertilisation of newly reclaimed land. Maatalous ja Koetoiminta 18: 44-59.

Salonen, M. \& Tainio, A 1956. Savimaan lannoitusta koskevia tutkimuksia. Summary: Investigations concerning the manuring and fertilizing of clay soils. Publications of the Finnish State Agricultural Research Board 146. $86 \mathrm{p}$.

Salonen, M. \& Tainio, A. 1957. Fosforilannoitusta koskevia tutkimuksia. Summary: Results of field experiments with different amounts of phosphate fertilizers. Publications of the Finnish State Agricultural Research Board 164. $104 \mathrm{p}$.

Sillanpää, M. 1982. Micronutrients and the nutrient status of soils: a global study. FAO Soils Bulletin 48.444 p.

Sippola, J. 1980. The dependence of yield increases obtained with phosphorus and potassium fertilization on soil test values and soil pH. Annales Agriculturae Fenniae 19: 100-107.

Uusitalo. R. \& Jansson, H. 2002. Dissolved reactive phosphorus in runoff assessed by soil extraction with an acetate buffer. Agricultural and Food Science in Finland 11: 343-353.
Vaishvila, Z., Matusevichius, K. \& Mazhvila, J. 2000. Amount of phosphorus in the soils of Lithuania and its role in optimization of agricultural crops nutrition. Potassium and Phosphorus: fertilisation effect on soil and crops. Proceedings of the Regional IPI Workshop, October 23-24, 2000 Lithuania. p. 85-91.

Vuorinen, $\mathrm{J} \&$ Mäkitie, O. 1955. The method of soil testing in use in Finland. Agrogeological Publications 63. 44 p.

Wechsung, G. \& Pagel, H. 1993. Akkumulation und Mobilisation von Phosphaten in einer Schwarzerde im Statischen Dauerversuch Lauchstädt - Betrachtung der PBilanz nach 84 Versuchsjahren. Zeitschrift für Pflanzenernährung und Bodenkunde 156: 301-306.

Yli-Halla, M. 1989. Effect of different rates of $P$ fertilization on the yield and $\mathrm{P}$ status of the soil in two long-term field experiments. Journal of Agricultural Science in Finland 61: 361-370.

Yli-Halla, M., Sippola, J. \& Saarela, I. 1997. Increase of potential phosphorus leaching at high soil test concentrations. Kungliga Skogs- och Lantbruksakademiens Tidskrift 137: 187-189.

\title{
SELOSTUS
}

\section{Vuosittain toistetun fosforilannoituksen vaikutus Suomen peltokasvien satoon I. Savi- ja hiuemailla saadut sadonlisäykset}

\author{
Into Saarela, Yrjö Salo ja Martti Vuorinen \\ Maa- ja elintarviketalouden tutkimuskeskus
}

Useimmilla pelloilla 1940-luvulla alkanut runsas fosforilannoitus on parantanut Suomen viljelymaiden alun perin heikkoa kykyä luovuttaa kasveille fosforia. EteläSuomen ja länsirannikon savi- ja hiuemaat ovat kuitenkin osoittautuneet paremmiksi fosforin lähteiksi kuin sisämaan hiesuiset ja karkeat maat. Viiden vuosittain annetun fosforimäärän vaikutuksia viljojen ja muiden kasvien satoon tutkittiin 12-18-vuotisilla kenttäkokeilla savi- ja hiuemailla.

Tutkimukset osoittivat, että Suomen savien ja hiukeiden fosforivarat riittävät useiksi vuosiksi suhteellisen hyvien satojen tuottamiseen. Suuret fosforilannoituksella saadut sadonlisäykset ovat todennäköisiä vain pelloilla, joiden viljavuusanalyysin P-luku on huono, $\mathrm{pH}$-luku liian alhainen tai $\mathrm{pH}$ on poikkeuksellisesti liian korkea. Myös maan huonosta rakenteesta ja kuivumisesta johtunut tehoton ravinteiden otto lisää fosforilannoituksen tarvetta. Ilman fosforilannoitusta saatu sato (maan Pluku $15,5 \mathrm{mg} / \mathrm{dm}^{3}$ ) oli keskimäärin $94,6 \%$ riittävällä fosforilla saadusta sadosta (4000 $\mathrm{kg}$ tai ry/ha) vaihdellen $87 \%$ :sta maan P-luvulla $2,8 \mathrm{mg} / \mathrm{dm}^{3} 100 \%$ :iin P-luvulla $50 \mathrm{mg} / \mathrm{dm}^{3}$. Runsasmultainen, liejuinen hiue tuotti täyden sadon myös maan P-luvulla $8,5 \mathrm{mg} / \mathrm{dm}^{3}$. Riittävästi kalkituilla mailla saatiin ilman fosforilannoitusta $95 \%$ runsaalla fosforilannoituksella saadusta sadossa, kun maan P-luku oli 5-7 mg/ $\mathrm{dm}^{3}$. Korjatun sadon fosforisisältöä (14 kg 4 viljatonnissa) ja uuttuvan fosforin keskimääräistä pidättymistä (6 kg/ha) vastaavalla sijoituslannoituksella $(20 \mathrm{~kg} / \mathrm{ha} \mathrm{P})$ tällainen maan fosforitila riitti edullisina kasvukausina lähes täyteen satoon. Maan Pluku $5-7 \mathrm{mg} / \mathrm{dm}^{3}$ arvioitiin pitkällä tähtäyksellä optimaaliseksi. Liejusaville sekä syvä- ja runsasmultaisille aitosaville riitti vaihteluvälin alapää, muille saville ja hiukeille tarvittiin alueen yläpäätä vastaava P-tila. 